\title{
Allocation under Dictatorship: Research in Stalin's Archives
}

\author{
Paul Gregory and Mark Harrison ${ }^{*}$
}

We survey recent research on the Soviet economy in the state, party, and military archives of the Stalin era. The archives have provided rich new evidence on the economic arrangements of a command system under a powerful dictator including Stalin's role in the making of the economic system and economic policy, Stalin's accumulation objectives and the constraints that limited his power to achieve them, the limits to administrative allocation, the information flows and incentives that governed the behavior of economic managers, the scope and significance of corruption and market-oriented behavior, and the prospects for economic reform.

\section{Introduction: A Well-Documented Dictatorship}

$\mathrm{T}$ he Soviet planned economy was the most important socioeconomic experiment of the twentieth century, and it underpinned the century's most elaborate and durable dictatorship. It was a major obstacle to the study of this experience, however, that the Soviet state also took secrecy to an extreme.

When the Soviet Union collapsed in 1991, many historical secrets were laid bare.

\footnotetext{
* Gregory: Professor of Economics, University of Houston, and Research Fellow, Hoover Institution on War, Revolution, and Peace, Stanford University. Harrison: Professor of Economics, University of Warwick, Distinguished Visiting Fellow, Hoover Institution, and Senior Research Fellow, Centre for Russian and East European Studies, University of Birmingham. The authors thank Eugenia Belova, Valery Lazarev, Roger Sherman, and the referees for their comments, and the Hoover Institution and its archives department, the National Science Foundation, the Leverhulme Trust, and the British Academy for financial and other support of their research.
}

These were documents never intended for publication or scholarly research: secret plans, reports, minutes, decisions, appeals, and the official and private correspondence of citizens from the highest authorities in the Kremlin to the humblest provincial petitioner. In Russia, these records are now held by the Federal Archival Service. 1 The scale and scope of its holdings are vast and intimidating, running to hundreds of millions of files. The Soviet state intervened everywhere,

\footnotetext{
${ }^{1}$ The main federal archives of interest to economists are the State Archive of the Russian Federation (GARF); the Russian State Economic Archive (RGAE); the Russian State Military Archive (RGVA); and the Russian State Archive of Social and Political History (RGASPI) and Russian State Archive of Contemporary History (RGANI) which together hold the records of the Soviet communist party. The Archive of the President of the Russian Federation (APRF) and the Central Archive of the Federal Security Service of Russia (TsAFSBR) would also be of great interest were they not largely closed to outsiders. A gateway to web-based information on former Soviet archives is provided under the Political Economy Research in Soviet Archives website at http://www.warwick.ac.uk/go/sovietarchives/archives.
} 
standing guard over state property, public morality, and most aspects of social life; its recording of decisions and outcomes was meticulous. While political power and economic organization always rested on a bedrock of informal relationships, the degree to which the exercise of power was expressed in writing is nonetheless staggering. There was no question of Stalin ever avoiding formal association with difficult decisions or passing them along by word of mouth.

Although Putin's Russia has remained protective of Soviet secrets of the 1960s and since, the opening of the archives has stimulated a true revolution in the history of the Stalinist state. ${ }^{2}$ Many volumes of documents have been published to aid those who are themselves unable to work in the archives. 3 While some sensitive documents of the period remain classified in the archives of the president and the security and military agencies, even the most secret institutions-the labor camps and the defense industry-are now being massively documented by new collections. ${ }^{4}$ Significant microfilm holdings are also available outside Russia, for example in the Hoover Institution.

\footnotetext{
${ }^{2}$ Among the landmarks of this revolution see, in particular, Stephen G. Wheatcroft and R. W. Davies (1985), Davies (1989a, 1996), Oleg Khlevnyuk (1993, 1996), E. A. Rees (1997a, 2001, 2004), J. Arch Getty and Oleg Naumov (1999), Yoram Gorlizki (2001a, 2002), Davies and Wheatcroft (2004), and Gorlizki and Khlevnyuk (2004).

${ }^{3}$ Khlevnyuk, Kvashonkin, Liudmilla P. Kosheleva, and Larisa A. Rogovaia (1995); Lars Lih, Naumov, and Khlevnyuk (1995); A. Berelovich and V. P. Danilov (1998); Berelovich (2000); Khlevnyuk, Devis [Davies], Kosheleva, Ris [Rees], and Rogovaia (2001); Khlevnyuk, Gorlitskii [Gorlizki], Kosheleva, Miniuk, Prozumenshchikov, Rogovaia, and Somonova (2002); Davies, Khlevnyuk, Rees, Kosheleva, and Rogovaia (2003). These include Stalin's correspondence, secret police reports, state planning commission and ministerial records, and Politburo reports. Another notable series covers agriculture and collectivization (Danilov, Roberta T. Manning, and Lynne Viola 1999 continuing).

${ }^{4}$ Forced labor: V. P. Kozlov (2004); the defense-industry complex: R. S. Ganelin (2003) and V. A. Zolotarev (forthcoming).

${ }^{5}$ Further information is available at http://www. hoover.org/hila/projectsarch.htm.
}

This survey summarizes the first fruits of archival research on the political economy of the Soviet Union in the period of "classical socialism" (János Kornai 1992) that ended with Stalin's death in March 1953. We cover topics of interest to comparative economists, institutional economists, political economists, and new economic historians. As for findings of specific interest to country specialists on Russia and the former Soviet Union, we discuss them only in passing.

In making this survey, we are well aware of the debt we owe to previous generations of western scholarship. Despite the obstacles of secrecy and censorship, the quantity of this scholarship was large and its quality high enough to warrant many publications in top economics journals. As a fresh generation has grappled with new evidence, there has inevitably been a certain amount of reinventing the wheel; it has been one of our tasks to try to discern what is genuinely new. Following the organization of our paper, we summarize this as follows.

Part 2 deals with the economic organization of dictatorship in a hierarchical command system. Before the archival revolution, scholars had almost no direct evidence of the political economy of centralized power; we saw mainly what reached the public or touched the lowest levels of economic administration. In politics, Kremlinologists made an educated guess at the shifting influence of moderate and radical factions; economists tended to presume a powerful role for technocratic central planners. We had little idea of what Stalin really wanted or what constrained his ability to get it.

${ }^{6}$ R. W. Davies, whose own work towers over the field, and others have surveyed the major findings from the standpoint of Russian history (Davies 1989b, 1997, 2003; Sheila Fitzpatrick 1999; Khlevnyuk 2001a; Gábor Rittersporn 2001).

${ }^{7}$ The economic journals currently archived at JSTOR published 320 articles on aspects of the Soviet economy between 1920 and 1991; half of these appeared in just three journals, the American Economic Review, the Review of Economics and Statistics, and the Journal of Political Economy. A catalogue is provided under http: //www.warwick.ac.uk/go/sovietarchives/before. 
The archives demonstrate that Stalin's personal dictatorship was real and, from 1932 onwards, unchallenged. Through his ten-man Politburo, Stalin was continually immersed in economic decisions. His Politburo guided the general direction of the economy by infrequent major decisions relating to investment and innumerable detailed interventions relating to outputs and inputs. There were no moderates or radicals; the Politburo was unified on general strategy, but divided by the special interests of its members, the expression of which Stalin particularly feared. The economy itself featured extreme centralization and the priority of vertical over horizontal relationships. Given that the Politburo could make only a few of the decisions that mattered, it delegated much of its power to lower levels in complex hierarchies to create a nested dictatorship of many smaller "dictators." Since each player distrusted those below him and those below knew any decision could be revised by those above, even trivial issues tended to be passed upward. The result was a "dictator's curse": despite the intention to delegate, Stalin had to make many more decisions than he wished.

Part 3 deals with the limits on Stalin's power to extract a surplus. Before the archives, we knew the published economic plans, decrees, and speeches that promised an ever-brighter future for Soviet producers and consumers, but even the best informed could only speculate as to the economic policy that lay beneath (Eugène Zaleski 1971, 1980). Most basically, we did not know the economic fundamentals in the dictator's objective function nor how he would trade them against political and other objectives.

The record of Politburo decisions, combined with our knowledge of the information that Stalin monitored most closely, suggests that Stalin aimed to maximize the economy's surplus, defined as output less consumption. His horizon was distant enough to make accumulation his first use of this surplus as long as war did not immediately threaten. Stalin saw this surplus as depending critically on worker incentives; he managed these by giving unflagging attention to consumption. While keeping consumption low, he feared that at any time it could fall so low as to promote worker revolt. This accumulation model explains why investment became volatile. The workers' consumption minimum was not a given and Stalin sought to reduce it by coercive means. The archives have recorded the consequences of extensive coercion, many of them unintended and perverse. Having created a surplus, Stalin had to hold rent seekers at bay. For the first time, we can witness the rent-seeking process. Special interests formed immediately within the dictator's own circle, leaving Stalin and a few associates to battle for the interests that they viewed as encompassing.

Part 4 deals with allocation in the economy as a whole. Before the archives, we already knew a great deal about shortages, queues, and corruption. The relationship between these was hotly debated: were shortages the unintended result of the famous "soft budget constraint" (Kornai 1980), for example, or were they intentionally created for corrupt purposes (Andrei Shleifer and Robert W. Vishny 1992)? By implication, if shortages led to corruption, was corruption the intended or unintended consequence?

Archival research has shown clearly how the soft budget constraint operated and where it came from. It originated in Stalin's industrialization drive and was perpetuated by his inability to commit to financial discipline. The "softening" process is significant because the channels through which it operated help explain the unexpected interest of producers in higher prices and money, including traceable bank money. The archives provide no support for the proposition that a shortage economy was created to increase rent-seeking opportunities. Still, despite extensive shortages, money remained a prized commodity and 
producers pushed inexorably for higher prices, contrary to previous stereotypes of the command system. There were markets or market-like institutions everywhere. These markets did not work well, were severely circumscribed, and relied heavily on relational enforcement.

Part 5 deals, finally, with efficiency, growth, and economic reform. Before the archives, we already knew that the Soviet economic system did not work that well. In early studies of enterprise managers, David Granick (1954) and Joseph S. Berliner (1957) uncovered massive principal-agent problems. Investment choices were made without rational criteria (Gregory Grossman 1953). Prices failed to reflect scarcity values (Abram Bergson 1964). The evidence of substandard postwar growth was overwhelming (Bergson 1978; Gur Ofer 1987; William Easterly and Stanley Fischer 1995) and increasingly preoccupied the country's leadership; the system seemed incapable of significant reform (Gertrude E. Schroeder 1973, 1979, 1982; Philip Hanson 1983; Morris Bornstein 1985; Vladimir Kontorovich 1988).

Research in the archives has shown how decisionmakers at every level actually allocated resources: They made it up as they went along, using intuition, historical precedent, and common sense. As befits a bureaucracy, there were plenty of formal rules, but the rules were constantly revised or overridden. Those at higher levels made formal rules, only to break them. Those at lower levels, unable to live without rules, relied on customary norms or rules of thumb. The flaws in this planned economy became apparent to its leaders almost immediately. Before the archives, we believed that official proposals for decentralizing economic reform began to circulate after Stalin's death; the first serious reform experiment actually dates to 1932 and bears a strong resemblance to reform proposals after Stalin's death. But, like all those that followed, it was quickly frustrated.

\section{The Dictator, Hierarchy, and Economic Policy}

Marx, Engels, and Lenin paid almost no attention to how socialism would organize itself politically or economically. In their pioneering discussion of socialism, Mises (1920 reprinted 1935), F. A. Hayek (1937), Barone (1908/1935), and Oskar Lange (1964) effectively set this issue aside by assuming a technocratic Central Planning Board inculcated with welfare-maximizing goals that dealt directly with enterprises. As a result, the "socialist controversy" (Bergson 1966) became focused on calculation and incentives. In terms of the real character of highlevel decision making in the Stalinist state, archival documentation has given us completely new knowledge. This regime was indifferent to calculation, preoccupied by the need to punish and deter its enemies, and bent on implementing its decisions through a complex administrative hierarchy of agents motivated by threats and promises.

\subsection{Stalin as Dictator}

Early archival investigations, focused on Stalin's role in the Great Terror, showed that he orchestrated it to a surprising degree (Khlevnyuk 1995), although he may not have intended all its consequences (Getty and Naumov 1999; Rittersporn 2001). Stalin's complete authority is revealed in how he was able to turn various major policies on and off, for example, stopping the Great Terror with a single memorandum (reproduced in Kozlov 2004 , vol. 1). The same conclusion applies to Stalin's role in economic decision making.

From approximately 1932 until his death, Stalin was a true dictator: he had his way on every matter and was not afraid to abuse and humiliate those on whom he depended most closely (Davies 2001a; Davies, Melanie Ilič, and Khlevnyuk 2004; Rees 2004; Gorlizki and Khlevnyuk 2004). As Khlevnyuk (2001a, p. 325: emphasis added) has concluded, "Stalin himself was not merely a symbol of the regime but the leading figure who made 
the principal decisions and initiated all state actions of any significance." Stalin was personally informed about and gave time to large numbers of minor matters. Stalin's preeminent role does not mean that he was in control of the consequences of his decisions. On the contrary, his correspondence is full of concern about "paper fulfillment" and of angry calls for "implementation" committees and monitoring fulfillment by placing responsibility on designated officials (Gregory 2004, pp. 165, 266).

What role did Stalin's colleagues play? In the late 1920s and at the beginning of the 1930s, decision making in the ten-person party Politburo was still collective. Already acknowledged as the senior personality, Stalin still had to bargain and cajole to get his way (Khlevnyuk 1996; Rees and D. H. Watson 1997). Dissenting Politburo members were obliged to support majority decisions in public while bringing disputes to the full Politburo for resolution, procedures that Stalin conveniently ignored during his power struggle with the "right deviationists" Bukharin, Tomskii, and Rykov. In the course of this power struggle, Stalin also cultivated the support of regional leaders and other members of the larger party Central Committee, the venue for the ultimate denouement of the power struggle in 1929 and 1930. The archives confirm that Stalin exercised great cunning, patience, and selfcontrol in organizing his Politburo majority and Central Committee support to oust his last rivals.

After 1930, Stalin increasingly bypassed the formal procedures for party consultation and committee decisions; this is reflected in the declining frequency of Politburo meetings, which fell from weekly in 1929 to only one in the second half of 1937 (Rees and Watson 1997). While formal meetings fell away, Stalin met increasingly with his associates in private where he could control participation and agendas directly (Wheatcroft 2004). He reached decisions alone or with ad hoc subcommittees that he personally appointed and scheduled, an arrangement that continued until his death in 1953 with little change. One element of formality remained: Stalin continued to bind his associates into complicity by requiring each Politburo member to approve his decisions once he had made them (Gorlizki and Khlevnyuk 2004).

The erosion of collective rule is consistent with Hayek's (1944) insight that the rise of a sole dictator is inevitable in such an environment; this leaves unsolved the puzzle of its partial restoration after Stalin's death. Stalin's ascendancy is explained by the need for a tie breaker within the Politburo and the fact that Stalin was more ambitious, brutal, and controlled than his rivals. But why was a tie breaker necessary? Although political scientists and historians had speculated about ideological divisions within the Politburo after 1930, the archives have revealed no disagreements on the basic directions of foreign and domestic policies. There was no "moderate" group after the "right deviationists" were eliminated; therefore, there were no extremists either (Rees 2004, p. 47). The divisions that did exist within the Politburo were on lines of narrow self-interest based on departmental position.

Stalin, who made all top-level appointments personally, was deeply suspicious of professional administrators and technocrats and trusted only a few old Bolsheviks. He aimed to concentrate economic decisions in the hands of a small number of "reliable" people; the ethos that Stalin wanted to instill is summed up in the term proposed by Wheatcroft (2004): “Team Stalin.” Although he consulted with them regularly as individuals, Stalin conceived of his colleagues collectively as his instrument, not a consultative body. When, for example, he saw political dominance over Gosplan threatened, he ranted: "It is sometimes worse than that: Not Gosplan but Gosplan sections and their specialists are in charge [and are turning the Politburo] into a court of appeals or a council of elders" (Belova 
and Gregory 2002, p. 270). He placed Team Stalin members in positions for which he would hold them personally responsible and was dismayed when they began to represent narrower interests. As head of the party control commission, Ordzhonikidze, a fellow Georgian and former head of the Caucasian party, led the battle against "disloyal" managers; once appointed minister of heavy industry he became their ardent defender (Khlevnyuk 1993). As head of the party's transport oversight committee, Stalin's first deputy Kaganovich (interviewed by F. I. Chuev 1992 , p. 61) stood up for encompassing interests but began to demand more rails and investment immediately after he became transport minister.

Stalin railed against rent seeking within his narrow circle: "It is bad when we begin to deceive each other" (Khlevnyuk et al. 2001, p. 80). He complained bitterly about the "selfishness" of the minister of heavy industry, who pressed "on the state budget of the working class, making the working class pay with its currency reserves for his own inadequacy" and that the "use of funds must be discussed in the interests of the state as a whole, not only in the interests of [the ministry of heavy industry]" (Khlevnyuk et al. 2001, pp. 72, 88). He particularly loathed the deputy minister of heavy industry for "turning our Bolshevik party into a conglomerate of branch groups" (Rees and Watson 1997, p. 16).

Examples of Politburo figures choosing encompassing interests over their own are rare. One case was the first secretary of the Ukrainian party, who, unlike other regional secretaries, did not fight for lower grain collection targets with the result that Ukraine lost millions to starvation during the famine of 1932-33 (Davies and Wheatcroft 2004). The practice of top party officials representing narrow interests illustrates a point made by Khlevnyuk (2001a, p. 325): although the competition of interests "contradicted the principles of the dictatorship" it could also limit "the destructive consequences of hyper-centralization." In short, interests were not less moral for being sectional.

\subsection{Principals and Agents}

Team Stalin was responsible for bringing decisions forward and implementing them. The Politburo's own immediate staff was limited in the early 1930s to 230 specialists; below this layer were better-staffed ministries and state committees that often prepared decrees for the dictator. Team Stalin was assisted by a state planning commission, Gosplan, that employed 900 specialists of whom many were technocrats of initially questionable loyalty (Khlevnyuk et al. 1995). Team Stalin issued high-level decrees in the name of the government or its subcommittees for defense and the economy, but the most important state decrees were issued jointly with the Central Committee.

The order of issuing decrees was confusing even to the top leadership, and Stalin had to guard against improper invocation of the party's name by agencies seeking higher endorsements (Gregory 2004). Most decrees were issued to a restricted number of recipients on a need-to-know basis. Alongside the almost 4,000 decrees published between 1930 and 1941 were more than 28,000 secret ones, of which over 5,000 were so secret that they were known only to a handful of people (Davies 2001a). Rules on secrecy were themselves especially secret, which sometimes complicated enforcement (Harrison 2004).

Standard organization charts (Gregory 2004) show a vertical organization with the Politburo and central government at the top, aided by functional and control agencies such as Gosplan, the committees for state and party control, and the omnipresent interior ministry known in different periods as the OGPU, NKVD, or MVD. The actual "managers of production" were industrial ministries and regional authorities that planned and supervised production units. The archives dispel the pretence that principals and agents at all levels of the hierarchy 
united to build socialism, share information, and forego private profit. Rather, the managers of production who were responsible for results engaged in disputes with those to whom they were accountable (Belova and Gregory 2002; Gregory and Andrei Markevich 2002; Gregory 2004) that were usually resolved by informal means, although administrative and legal remedies were also available (Belova 2005).

Formal links among industrial ministries, regional authorities, or among enterprises, are notably absent despite the fact that horizontal transactions are the basis of specialization and exchange in all economies. Unauthorized horizontal links represented a troubling problem for the dictator. On one hand, a principal gives an order to an agent precisely because the allocation that the principal desires differs from the one that would result from the agent's trading on her own account. Hence, the obedient agent must be induced to forego opportunities to trade for private gain. On the other hand, frequent planning mistakes ensured that orders issued from above could not be implemented unless supported by unauthorized transactions, even the barter of "an ordinary suitcase full of cigarettes" (cited by Davies 1996, p. 266). Such horizontal transactions (again to cite Khlevnyuk) "contradicted the principles of the dictatorship" but limited "the destructive consequences of hyper-centralization."

\subsection{Planning With a Light Touch}

When key decisions were taken by Team Stalin, usually on Stalin's personal authority, what role was left for the planning professionals? Textbook accounts (Gregory and Robert C. Stuart 1974; Alec Nove 1977) suggest that Gosplan exercised considerable executive power over allocation. For the Stalin period at least, this view requires revision: Gosplan was important, but it was not powerful, and surprisingly sought to limit its own power.
Gosplan was established in February 1921 to institute and operate a "unified state plan" for the whole economy and harmonize the plans of other economic departments. It was modestly endowed for these grand tasks and still had only fifty specialists in 1925. In 1929, Stalin made it clear that he was not interested in "balances" and "limits" that restricted his freedom of action. The purge of Gosplan that followed famously tested "the civil courage of those specialists who are already admitting in the corridors that they prefer to stand up ... for high rates of expansion than to sit [in jail] . . . for low ones" (a plan official in 1929, cited by Edward H. Carr and Davies 1969, p. 938). At the same time a planned economy was being laid down, those who were trying to create its intellectual foundations were being "hound[ed] out of Moscow" in accordance with Stalin's instruction (cited by Belova and Gregory, 2002, p. 271). 8

Gosplan prepared only plans that were highly aggregated, stating: "Gosplan is not a supply organization and cannot take responsibility either for centralized specification of orders by product type or by customer or the regional distribution of products"(cited by Gregory 2004, p. 139). Gosplan refused to plan horizontal transactions in detail, labeling the latter "syndicate work" (Belova and Gregory 2002). Gosplan did represent the government in interministerial conflicts and served as a reluctant consultant despite pleading that "we are simply not equipped to deal with such matters" (Belova and Gregory 2002 , p. 271). In short, after its purge and subsequent politicization, Gosplan limited its exposure by doing as little as possible. It was not until the late 1940s that Gosplan

\footnotetext{
${ }^{8}$ Gosplan's politicization had less of an impact on practice than one might imagine because, in the early 1930 s, its methods were still primitive. Gosplan's most comprehensive centralized balances covered only thirty raw materials, eight energy sources, and four types of machinery allocated among large-scale industry, small-scale industry, food processing, and exports (Wheatcroft and Davies 1985, appendices $\mathrm{A}$ and $\mathrm{D})$.
} 
again became an activist organization under its young and influential chairman, Nikolai Voznesenskii.

The prevailing view of Gosplan before the archives exaggerated its role, at least for the Stalin period. Gosplan was not an all-powerful director of resources; the power belonged to the dictator. Stalin did not want a planning board with immense powers or numerous staff. Why then did he keep it in being? Stalin had need of a relatively small agency on which he could rely to tell him the truth. He held most of those around him accountable for results and for that reason did not trust them to report outcomes truthfully. That was the specialized task of Gosplan, which became Stalin's solution to the wider principal-agent problem (Belova and Gregory 2002. Typically, Stalin also gave overlapping responsibilities to other agencies such as the economic administration of the NKVD. Gosplan's leaders did not have to make a success of the economy in order to retain Stalin's trust; that was the job of the ministers for the production branches. All Gosplan had to do was to report honestly. This did not necessarily make an independent Gosplan leader such as Voznesenskii popular with the other top party managers. Voznesenskii was one of Stalin's favorites while Stalin trusted him. When the others found an opportunity to sow distrust with the boss, Stalin had him shot (Gorlizki and Khlevnyuk 2004).

\subsection{Rules Versus Discretion}

Hierarchical organizations resort to contingent rules, customs, and conventions to make boundedly rational decisions. Bergson (1966) suggested that contingent rules could resolve a number of problems, such as opportunism and computation, specific to a planned economy. Hayek (1944, p. 82) asserted to the contrary that a totalitarian system "cannot tie itself down in advance to general and formal rules that prevent arbitrariness ... It must constantly decide questions which cannot be answered by formal principles only." The archives show that Hayek was right. 9

While the Soviet economy was managed by decree, there were few formal stable rules; the rules that existed were subject to override. Fresh guidelines were issued to plan each new year or quarter, rather than carry over general planning rules. Ministries operated without charters that spelled out corporate governance (Gregory and Markevich 2002). The few accounting and loan administration rules were easily ignored with the tacit approval of Team Stalin (Gregory 2004); the enforcement of financial targets and value-for-money was selective and arbitrary. Rather than let the courts enforce legal interagency agreements, Team Stalin allowed and encouraged "administrative" enforcement through appeals to vertical superiors (Belova 2005).

Hayek's expectation of the dictator's aversion to formal rules is exemplified by the operational plans that enterprises were obliged to fulfill by law (Belova 2001). The formal procedures were complicated, contradictory, and confusing for the actual participants (Markevich 2003). In the Stalin era, the operational plan for the enterprise was not the unified output, input, finance, technology, and labor plan [tekhpromfinplan] that Soviet and western planning texts describe. Rather, the enterprise usually received a few output and assortment assignments midway through the plan period, while secondary targets for costs and productivity were worked out retrospectively for reporting purposes.

\footnotetext{
${ }^{9}$ Contingent rules that guide decision making feature in two different economic literatures, both of which are relevant to the present survey. The rules-versus-discretion literature refers to formal stable rules, for example, those that govern taxation. In this context, it is a problem if the agent can too easily ignore or renegotiate such a rule. This was Hayek's point. The bounded-rationality literature discusses customary rules or rules-of-thumb that are made informally and evolve as agents struggle with computation constraints and uncertainty. In this context, it is a problem if such rules lead to systematic errors. Our point is that the Soviet command system was intolerant of formal rules; on the other hand, informal rules-of-thumb proliferated.
} 
A surprising feature of the working archives of ministries and enterprises is the near total absence of final "approved" plans. All plans were labeled "draft" or "preliminary." The draft plan was no more than an informal agreement which could be changed subsequently by virtually any superior. The "correcting" and "finalizing" of plans was a never-ending process; the "final" plan remained always on the horizon. Searches in the ministerial archives have located only one finalized annual plan, that for light industry in 1939 (Markevich 2003).

The archives provide thousands of cases of plan revisions. Ministers ordered last minute changes; factories were shuffled from one authority to another; one factory was ordered to increase its production post haste to make up for production shortfalls in another factory. Even Politburo commission decisions could be changed at the last minute: Although the first-quarter 1933 vehicle distribution plan had been approved by its own transport committee, the Politburo threw the plan out the window by tripling the Kazak party committee's allocation and dedicating 90 percent of the vehicles to "organs of control over agricultural producers" (Valery Lazarev and Gregory 2002, p. 332).

Each level received a barrage of requests to intervene or to refrain from intervention in a highly formalized bureaucratic process. In deciding how to respond, Team Stalin did use some implicit rules-of-thumb, such as the priority of heavy industry and the military. Thus the minister of heavy industry: "All orders for the Ministry of Defense must be fulfilled exactly according to the schedule not allowing any delays" (cited by Gregory 2004, pp. 160-61). Enterprises cited priority considerations to defend against interventions. Military shipbuilders in 1935 ignored orders from the highest state authority on the grounds that they interfered with military objectives (Gregory 2004). Priorities, however, had to be limited to be effective, and the priority statements issued by leading authorities were often either too broad or too specific (Gregory 2004 gives examples). Delegating the right to intervene to lower levels was dangerous, however, since it was a problem to align the interests of lower agents with those of the dictatorship as Bergson (1964) once pointed out.

Plan interventions created havoc for producers. A meeting of industrial ministers held in December 1946 turned into a representative complaint session. The minister of the electronic industry: "During the quarter, even during the month, there are a great number of changes, modifications, and additions to the approved plan. We do not usually work according to the plan; rather we work on the basis of supplemental decrees, administrative decisions, and the like ..." The minister of the aviation industry: "It is better to have one plan than to change it twenty times" (Markevich 2005). The most important industrial leader of the 1930s expressed his frustration as follows: "They give us every day decree upon decree, each one is stronger and without foundation" (Khlevnyuk 1993, p. 32).

Ministries and enterprises insured themselves against interventions by holding back obligatory information and submitting their own plan proposals at the last minute to avoid duplicating this work later; ministries often proposed relatively modest targets to Gosplan while quietly imposing tougher assignments on their own enterprises (Belova and Gregory 2002). Ministries fought for generalized plans and tried to avoid divulging enterprise plans to Gosplan; in April 1933, for example, Gosplan complained that ministry plans "suffered from such incompleteness that it is impossible to use them" (Belova and Gregory 2002, p. 274). The ministries withheld information from Gosplan and financial authorities on grounds of national security (Belova and Gregory 2002; Harrison 2004). For producers, the best plan was either no plan at all or a plan so general that it left all the real decisions to them. Gosplan even uncovered cases of "nonplanning": "Enterprises [large enterprises located near Moscow] declared 
to our representatives that they had not seen annual plans for a period of years" (cited by Belova and Gregory 2002, p. 275).

Stalin (1937, p. 413) wrote: "Only bureaucrats can think that planning work ends with the creation of the plan. The creation of the plan is only the beginning. The real direction of the plan develops only after the putting together of the plan." Team Stalin maintained the right to override plans at will because this provided "resource mobility." In practice, such procedures served the interests of principals at every level and could not have been better designed for the exercise of political influence. Everything was tentative and subject to arbitrary change by someone higher up in the chain of command. No one can know what went on behind the scenes when petitioners met with superiors, but we can guess that savvy politicians like Stalin would weigh the political benefits of satisfying an influential regional or industrial leader.

The aversion to explicit rules reflected the dynamic commitment problem of a dictator. Stalin's unwillingness to bind himself in advance cascaded down through the political system, preventing the emergence of a formally rule-based or "law-governed" economy. Kornai, Eric S. Maskin, and Gerard Roland (2003) suggest two kinds of commitment failure: in one, a predatory principal forces agents to break formal rules so as to exploit them; in the other, agents choose to break the same rules so as to exploit a weak principal. In the Soviet case, producers could break rules citing the threat to production from the rule, while superiors reserved the right to punish hapless scapegoats for breaking the same rules. It is sometimes hard to detect whether such rule breaking reflected the power of officials to force producers to commit violations or the ability of producers to commit violations and get away with them.

Generally, to exploit power to the full involves encountering its limits. Specifically, it was the power to live outside formal rules that sentenced Stalin and his Politburo to lives of toil, drudgery, and tedium (Gregory 2004). Threats of resignation and pleas for lengthy vacations were commonplace. A representative Politburo meeting, held on March 5,1932 , had 69 participants and 171 points on its agenda (Khlevnyuk et al. 1995). The greatest burden fell on Stalin who, in a typical year, 1934, spent 1,700 hours in official meetings, the equivalent of more than 200 eighthour days (Khlevnyuk 1996). Virtually every communication requested his decision.

On rare occasions, Stalin would explode at this torrent of paperwork, for example in a tirade of September 13, 1933: "I won't read drafts on educational establishments. The paperwork you are throwing at me is piling up to my chest. Decide yourself and decide soon!" (Khlevnyuk 1996, p. 340). A few weeks later the same Stalin berated the Politburo for not following his proposed distribution of tractors to the letter (Khlevnyuk 1996). Stalin suffered the dictator's curse (Gregory 2004): his power to decide all gave his most trusted colleagues the incentive to decide as little as possible. The less they decided, the less he could blame them when things went wrong.

\section{Accumulation and Consumption}

Before the archives, we could only guess at Stalin's real economic policy. Would the dictator foster economic growth (Mancur Olson 1993; Edward Glaeser et al. 2004)? To what extent would he share his rents to build loyalty or increase his political power (Ronald Wintrobe 1998)? The archives tell us that Stalin was obsessed with accumulation, which is hardly a surprise. Between 1928 and 1937, Soviet real GNP doubled, but the fierce repression of private consumption enabled a quadrupling of real investment (Bergson 1961). More generally, investment rates in socialist countries were consistently higher than in capitalist countries of comparable size and income levels (Simon Kuznets 1963).

Without information on high-level decision making, the prearchival literature had 
little to say about aggregate investment choice. ${ }^{10}$ Bergson argued (1964, p. 241) that investment depends "on the output mix to be produced from it"; this view percolated through the various editions of textbooks (Gregory and Stuart 1974). Hence, the prevailing prearchival view was that the dictator's primary target was output, from which investment was derived. The archives show that this view was wrong: Stalin and the Politburo attempted to control the basic direction of the economy through the level and distribution of investment. They were less concerned about setting physical outputs in operational plans.

The literature on how a socialist economy ought to determine aggregate investment stems from Marx's emphasis on accumulation and proceeds via the growth models of Preobrazhenskii and Feldman in the early Soviet period (Alexander Erlich 1960; Nicolas Spulber 1964) to the later models of Brus, Kalecki, and Dobb (Peter Rutland 1985). The earlier models suggest that the feasible investment rate depends on the balance of power in the economy and the scope for expropriating the "former" social classes. The later models suggest that the optimal investment rate depends on society's discount rate, but that a labor-abundant market economy may underinvest if the realized subsistence wage is above the shadow wage. No Politburo member was trained in economics, however; nor did they feel the lack of such training.

\subsection{The Politburo Accumulation Model}

At the core of the Politburo's strategy to "build socialism" in the first two five-year plans, were massive programs for the hydroelectric dams, machinery complexes, vehicle

\footnotetext{
${ }^{10}$ Bergson's authoritative Economics of Soviet Planning (1964) introduces investment first in chapter 11 and largely puts aside the issue of its total volume, focusing instead on rational choice of individual projects. The most widely cited paper on investment (Grossman 1953) deals exclusively with the choice to be made when a given increase in desired output could be obtained from alternative projects.
}

works, blast furnaces, railways, and canals that were included on its itemized "title lists" of approved projects. Their purpose was to embody the new society in cement and structural steel. How were these programs implemented and managed?

Although Politburo meetings for the 1930s left few formal minutes, his deputies wrote to Stalin from time to time to detail key Politburo meetings and seek approval of operational decrees (Gregory 2004). They reveal that the Politburo consistently set three targets in the 1930s: the nominal investment budget, grain collections, and foreign exchange. These three control variables all related to investment. The investment budget allotted funds to industrial and regional agencies for construction and machinery. Despite an original intent to use physical material balances of investment goods to plan investment, ministries and regional authorities were simply given "investment rubles," and no one appeared to know the real investment that resulted. Grain collections were designed to contribute to a budget surplus through the excess of state sale prices over purchase prices. Stalin personally directed foreign exchange to the import of capital goods rather than the luxury goods sometimes demanded by the Bolshevik elite.

If Stalin's goal was indeed to maximize investment, the archives provide two types of evidence that are, at first glance, confusing. First, Stalin was extremely concerned about consumption, particularly where it touched upon the productivity and morale of the industrial workers. Consumer supplies were one of the most frequent items on Politburo agendas; in Stalin's words, the "provisioning of workers" was one of "the most contested issues" before the Politburo and trade was "the most complicated ministry" (quoted by Gregory 2004, pp. 93-94). Stalin interpreted declining labor productivity as a sign that workers "were not provisioned as well as last year," and personally ordered the delivery of consumer goods to 


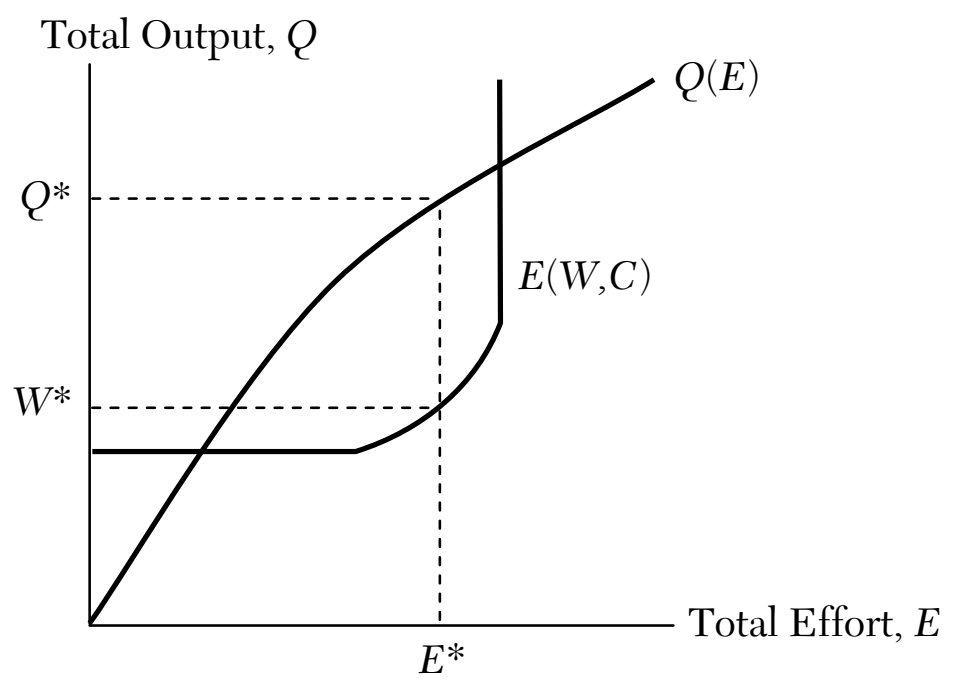

Figure 1. The Politburo Model

cities where labor productivity was declining (Gregory 2004). The Politburo set itself up as the highest trading organization, deciding retail trade plans, prices, assortment, and even the opening of new stores. Second, we have the little-known empirical fact that the Politburo, which based the success of its program on capital construction, deliberately reduced nominal investment on two occasions, in 1933 and 1937 (Davies 2001b) citing the fear of inflation and rising construction costs.

This evidence can be interpreted in two ways. One is that that Stalin's preferences were unstable; fitful humanitarian impulses led him to direct more supplies to the workers from time to time; periodic fits of financial orthodoxy led him to regret overstraining the economy. Alternatively, Stalin's preferences were stable and he reallocated consumption or reduced investment according to a consistent rule-ofthumb. Knowing of Stalin's capacity for calculation, patience, and self-control, we reject the first explanation and investigate further the second.
Figure 1 illustrates the model that the Politburo appears to have used to set investment and consumption. The figure mirrors the Marxian concept of the surplus product, the gap between output and consumption, as the outcome of a distributive struggle. The model has theoretical precursors in Wolfram Schrettl $(1982,1984)$ and Leon Podkaminer (1989), and is set out more fully by Gregory (2004). It belongs to a general class of models in which a ruler's freedom of action is circumscribed by social "tolerance limits" (Kornai 1980) or a revolution or disorder constraint (Daron Acemoglu and James A. Robinson 2000). By raising investment without limit, the Politburo risked provoking the workers to go slow, strike, or rebel.

The demand for labor was always enough for full employment and besides all ablebodied persons were required to work by law (Granick 1987), so the figure takes employment, $N$, as fixed exogenously; individual effort, $e$, was variable, so total effort, $E=e \cdot \bar{N}$, was variable although employment was not. Total output, $Q$, depended on total 
effort, $E$. Total effort varied with the real wage, $w$, as follows. The aggregate wage bill $W$, the consumer goods received by workers, is measured along the vertical axis in the same units as output, and is proportional to the real wage given that employment is fixed, i.e., $W=w \cdot \bar{N}$. There is a reservation wage, analogous to a tolerance limit or disorder constraint, below which effort is zero; there is also a "fair" wage at which effort is maximized.11 As the economy moves from the fair wage to the reservation wage, effort declines as workers turn up late or drunk, or go slow or absent without leave; at the limit, unrest simmers and threatens to boil over into local and general strikes and rebellion. Thus the effort curve intersects the horizontal axis at the reservation wage and becomes vertical at the fair wage. Effort also depends on the level of direct coercion, $C$, to which we turn in the next section. To maximize effort, the dictator would pay the fair wage and get the maximum output, but this would not maximize the surplus. To maximize the surplus, $Q-W$, he would choose the intermediate wage, effort, and output levels denoted $W^{*}, E^{*}$, and $Q^{*}$.

The shape of the effort curve is hypothetical; the hypothesis is Stalin's and can be inferred from his observable anxiety about errors in the distribution of consumer goods. An effort curve of this shape makes the consequences of plan mistakes asymmetric: for the dictator, paying the workers too little could be much worse than paying them too much. Starting from the investment optimizing position, more consumption does at least raise effort and output, and this somewhat mitigates the fall in investment. A mistake of the same size from

\footnotetext{
11 The fair-wage concept in figure 1 can be related to the observation of George A. Akerlof (1984) and Akerlof and Janet L. Yellen (1990) that workers in market economies give extra effort if they are paid a wage perceived to be fair, and withdraw it if the wage is reduced below the psychologically determined fair level. We suppose that effort has a maximum, so payments above the fair level do not elicit more effort.
}

the same starting point and in the opposite direction, however, not only cuts effort and output by more but also risks pushing the workers into outright confrontation with the state. An investment-maximizing dictator must tread a fine line between the pursuit of investment and the triggering of serious disorder.

Stalin managed worker morale and effort in two ways. When investment and consumption were about right in the aggregate, detailed plan mistakes could still leave some workers with too much and others with too little. When this happened, Stalin personally ordered the reallocation of consumer goods to those left short. But there could also be aggregate mistakes; when too much investment threatened to disrupt the economy and provoke the workers, the Politburo preferred to sacrifice investment. This is how we interpret the unforced investment cutbacks of 1933 and 1937. Although Stalin did not express his concern for consumption directly, when he advocated "strengthening the ruble" as a justification for less investment (Gregory 2004, pp. 236-42), it was the same ruble that workers had to spend in retail markets; when he feared rising construction costs, these were fiscal costs that had to be covered through taxation or the inflation tax. In this sense, Stalin's behavior was stable and consistent, given the constraints that he perceived.

Figure 1 suggests other options. Team Stalin could seek to manipulate the effort curve by offering ideological rewards in place of material payoffs. Idealists from Russia and abroad in fact assisted the first five year plan, motivated by the idea of building socialism. The attempt to transform homo economicus into homo sovieticus led, however, to a vicious circle of wage equalization and declining productivity (Hiroaki Kuromiya 1988; Davies 1989a, 1996). Subsequent mobilizations were limited to short lived campaigns such as for World War II, and to cultivate the "virgin lands" of Kazakhstan and Siberia after the 
war. The most publicized mobilization campaign of the 1930s, the Stakhanovite movement, was driven by progressive piece rates that permitted participating workers to drive up their incomes by overfulfilling norms (Davies and Khlevnyuk 2002); the archives suggest that Stalin abandoned it because it tended to raise fair-wage aspirations among nonparticipating workers, and also threatened inflation (Gregory 2004). Stalin could also elicit extra effort from party "enthusiasts" in the present by promising future promotion. The problem was that these promises eventually had to be made good. Lazarev (2005) has identified the creation of new posts that carried a wage premium to reward loyal supporters as an important feature of Stalin's policy. Relentlessly purging the potentially disloyal made it cheaper for him to keep his promises to the actually loyal.

In an extension of the model, the Politburo could bear down on consumption selectively via targeted rationing. Elena Osokina (2001) argues that Stalin wanted to drive down consumption and hence introduced a discriminatory ration. Julie Hessler (2004) argues that, on the contrary, Stalin approved of nonrationed trade and a consumption oriented lifestyle but crises (collectivization, rearmament, war, and postwar famine) allowed him to achieve this goal for only short periods. Gregory argues that Stalin saw rationing as a way to force accumulation without a loss of effort of high-priority workers according to the principle: "He who does not work on industrialization shall not eat" (cited by Gregory 2004, p. 98: emphasis added). Rationing carried other costs, however, as Stalin became aware (Davies and Khlevnyuk 1999).

Figure 1 has a further ominous extension. The fair wage was set by a mass psychology that was unpredictable and hard to manipulate. If workers concluded from the propaganda of economic successes that they were being cheated, the fair wage would rise, forcing the Politburo to cut investment back. Stalin used the vast informant network of the NKVD to monitor protests, strikes, anti-Soviet statements, and factory-wall graffiti, and eavesdrop to gauge mass opinion (Berelovich 2000). Stalin had obvious political motives to do this, but within our framework we conclude that wages and fairness lay at the cross-hairs of politics and economics.

\subsection{Coercion: Three Experiments}

In principle, efficient penalties are cheaper than efficient rewards since "a promise is costly when it succeeds and a threat is costly when it fails" (Thomas C. Schelling 1960, p. 177). In figure 1 , the fear of punishment may cause workers to lower their reservation wage without reducing effort; coercion may not make effort more productive but should make people willing to supply effort for less. As long as coercion displaces the effort curve downward while leaving the production curve undisturbed, the surplus is increased. In market economies, outside options, such as alternate employment, leisure, or unemployment, cannot easily be limited by force as the ubiquity of informal sector employment and illegal migration demonstrates. In the Stalinist state, however, the idea of controlling workers' alternatives by force proved attractive.

The archives show that Stalin believed that a wide range of problems could be solved by force. The language with which he addressed obstacles to his rule was habitually violent. Faced with foot-dragging in the transport ministry in 1931, he wrote: "we must smash this gang ... If you can manage without my help, smash the gang before it's too late." Considering the role of speculators in a legalized urban rural market, he wrote in 1932: "we must eradicate this scum ... The OGPU [secret police] and its agencies must, without delay, start training its forces and studying the enemy" (Davies et al. 2003, pp. $95,102,165)$. 
The archives have thrown new light on past controversies. Historians have argued about the extent to which Stalin's motives in the Great Terror of 1937-38 were primarily economic or political; thus Roberta T. Manning (1993) speculated that Stalin launched the terror in order to solve widespread economic difficulties, but the archives have not yielded any substantial evidence to this effect (Davies 2004). Rather, the aim of the terror was political: to isolate and remove a potential "fifth column" from society that, Stalin believed, could endanger his regime in a time of rising international tension (Khlevnyuk 1995). Of more interest to economists, some scholars have argued that coercion was the glue that held the Stalinist economy together. When coercion failed, or was abandoned, the economy fell apart (Kontorovich 1986; Olivier Blanchard and Michael Kremer 1997; Harrison 2002). Others have emphasized the huge social and economic costs of coercion (Robert Conquest 1987; Khlevnyuk 2001b; Davies and Wheatcroft 2004). Below we discuss the issues of whether coercion paid for itself and where the optimum lay.

Stalin conducted three notable experiments with the use of coercion to foster accumulation: the forced collectivization of the peasantry, the criminalization of workplace indiscipline, and the widespread use of forced labor. In each case, the outlines have been known for decades, but the full consequences are only now coming to light.

\subsubsection{Collectivizing Peasants}

Politically, collectivization aimed to impose Soviet power in the countryside and eliminate the stratum of richer peasants, the kulaks. It was triggered, however, by a grain marketing crisis that reflected the peasants' perceived unwillingness to contribute sufficiently to investment-led industrialization. Collectivization began in earnest in December 1929, signaling Stalin's victory in the power struggle. The relatively open discussion in the late $1920 \mathrm{~s}$ supported a substantial literature on the collectivization decision, the most complete account of which is by Davies (1980a, 1980b); James W. Heinzen (2004) has now added a study of the agriculture ministry in the 1920s. Naum Jasny (1949), Moshe Lewin (1968), and Erich Strauss (1969) outlined some general results. James R. Millar (1974) and Michael Ellman (1975) concluded that the investment surplus that Stalin hoped to gain from collective agriculture was probably not forthcoming. But the detailed consequences of collectivization and the mass deportation or detention of peasants who were excluded or resisted were concealed behind a thick veil of secrecy.

Mark B. Tauger (1991), Davies, Tauger, and Wheatcroft (1995), Wheatcroft and Davies (2002), and Davies and Wheatcroft (2004) have now reviewed the archives on the immediate aftermath of collectivization, including the famine of 1932-33. The collective farms enabled Moscow to replace local decision making with its own detailed plans, instructions, and formal, but often transient rules. Stalin was focused on what he could control: sown acreage and the state's share in what this acreage produced. But Stalin could not control the harvest. Acreage expanded but yields collapsed; the share delivered to the state increased. Excessive procurements, bad weather, and plan errors combined to strip the countryside of grain; first the livestock were slaughtered, then the farmers themselves starved. They were prevented from feeding themselves from their own harvests by severe punishments including death for petty theft. Davies and Wheatcroft dispel Conquest's (1987) notion that Stalin manufactured the famine to kill class enemies; rather they show the leadership subsequently trying to ameliorate the effects of its own bungling.

While famines usually occur in poor countries with limited statistical reporting, the Soviet archives provide good documentation of the two peacetime famines of 1932-33 and 
1946-47. Ellman (2000) has applied the entitlement theory of Amartya K. Sen (1981) to the latter famine, which particularly affected the peasants of the Ukraine and other southern regions. Sen argued from historical experience that famines are more likely to arise from entitlement or distributional failures than production failures, and that "no matter how a famine is caused, methods of breaking it call for a large supply of food in the public distribution system" (1981, p. 79). Ellman makes two points from the evidence.

First, he argues, in the 1946-47 famine, production and entitlement failures interacted. The production failure was not such as to leave insufficient food available to keep everyone alive. In this sense, the famine arose from a failure of entitlement. But the famine was triggered by a harvest failure; if the harvest had not failed, everyone would have had sufficient entitlements to stay alive. Therefore, the famine cannot be attributed to entitlement failures alone. Second, Ellman notes that in this famine the role of the state was essentially negative: it selected those who died by denying them entitlements. Therefore, it could be argued, concentrating grain stocks in the hands of the Soviet state actually increased the number of deaths. Davies and Wheatcroft (2004) show that, in 1932 and 1933, the state intentionally directed food to those able to work in the fields and denied it to those already hospitalized by hunger. Accordingly, the 5.5 to 6.5 million famine deaths in these years far exceeded those recorded in famines before the Revolution (Davies and Wheatcroft 2004).

\subsubsection{Regimenting State Employees}

As the 1940s began, Stalin redirected coercion from specific class enemies to the entire public-sector work force. A battery of intimidating laws criminalized work place violations which had previously been managed by administrative sanctions within the enterprise. The laws themselves were not secret and were described by Conquest (1967) and Nove (1969). Their consequences, however, remained obscure until the archives were opened.

The law of 26 June 1940 (Kozlov 2004, vol. 1) made absenteeism, defined as any twenty minutes' unauthorized absence or even idling on the job, a criminal offense, punishable by up to six months' corrective labor at work with a 25 percent reduction in pay. Repeat offenses counted as unauthorized quitting, punishable by two to four months' imprisonment. Enterprises managers were made criminally liable for failure to report worker violations. In August 1940, the minimum sentence for petty theft at work and "hooliganism" was set at one year's imprisonment. Wartime decrees punished defense and transport workers for unauthorized quitting with long terms in a labor camp. After the war, a notorious decree of June 1947 set the minimum sentence for any theft of state or socialized property at five to seven years imprisonment. Transport work was eventually demilitarized in March 1948 and work in the defense industry two months later; otherwise, these punitive laws remained on the books until Stalin died.

More liberal governments also took powers to direct their key workers in wartime, but the detail, scope, and degree of enforcement of the Soviet measures went to an extreme. A report prepared as background for Khushchev's secret de-Stalinization speech of February 1956 (Kozlov 2004, vol. 1, statistical appendix), shows that, from 1940 through June 1955, the regular courts and military, transport, and labor camp tribunals sentenced a total of 35.8 million persons for all criminal offenses. Not allowing for repeat offenders, this would represent about one third of the adult population of roughly 100 million. Of the 35.8 million, 15.1 million were imprisoned and a quarter of a million were executed. The annual rate of imprisonment was one million or more in most years up to 1950 , and more than half a million at the time of Stalin's death. Such conviction rates were about five times as large as in the 
United States at about the same time.12 These totals were dominated by workplace offenses (Don Filtzer 2002; Andrei K. Sokolov 2003, forthcoming) and by convictions for theft of socialized property (Kozlov 2004, vol. 1, statistical appendix).

The archives show that Team Stalin, not an independent judiciary, determined the number of convictions. When the laws were enacted, Stalin had to intervene personally to force a reluctant judiciary to prosecute tardy or lazy workers (Sokolov 2003).

\subsubsection{The Labor Camps}

Collectivization in the early 1930s, the Great Terror of 1937-38, the repression of state employees in the 1940s, and the arrests of "national contingents" during and immediately after World War II created huge flows into labor camps. In the 1920s, there was just one forced labor complex in the Arctic where mainly political detainees were held. The first major expansion came with collectivization which threw hundreds of thousands of peasants into camps or special settlements; the Gulag, the interior ministry's chief administration of labor camps, was created in 1930 to handle the sudden inflow and labor camps spread across the remote interior and the far north and east to house, at their peak, more than 2.5 million inmates.

Although the Gulag was shrouded in intense secrecy, its human side leaked out through the recollections of former inmates. Estimates of its scale and scope, however, could be based on little more than guesswork until the first official figures were released in 1989. While contemporary estimates of the

\footnotetext{
12 Given the many factors that differentiated the Soviet judicial and penal system from others, it is hard to find appropriate standards for detailed comparison of workplace offending. It is simpler to go to the aggregate of all offenses. From 1940 to June 1955, the USSR imprisoned 15.1 million people or, on an annual basis, roughly one percent of its adult population each year. In 1958, for comparison, the United States imprisoned not more than one fifth of one percent of its adult population (U.S. Department of Commerce 1960, pp. 139, 141). Thus Stalin imprisoned his subjects at least five times more frequently than the United States.
}

number of detainees ranged up to 20 million, we now know that there were approximately 2.3 million penal laborers at the outbreak of World War II and about 2.5 million at the time of Stalin's death; similar numbers of deportees were also confined to labor settlements in the remote interior. The forced laborers were mostly engaged in forestry, mining, and construction, where they made up substantial shares of employment, but never more than about 3 percent of the total workforce including farm workers, and less than this in terms of the value of national output (Khlevnyuk 2001b, 2003a).

These new facts must be set beside others, including the very high rates of conviction and sentencing that we now know about: although the Gulag population was smaller than observers had earlier guessed, it also had much higher turnover with very large numbers entering and leaving to return to society. While we are confident of the stocks of Gulag inmates at different points in time, the cumulative total of persons sentenced to the Gulag in the course of its existence, probably in excess of twenty million, remains the subject of debate. We now know that the Gulag's own central catalogs are inconsistent (Kozlov 2004, vol. 2); it appears that even the Gulag did not know the correct number.

Internal Gulag documents confirm that political strategy (collectivization, terror, war) rather than economics dictated the Gulag's development. Before the archives, there was speculation that in the course of the 1930s economics eventually took over from politics as a motivation for recruiting forced laborers, or alternatively that the NKVD became a lobby for forced labor (S. Swianiewicz 1965). Neither of these has turned out to be the case, although our judgment has to be carefully shaded.

The Gulag had a consistent economic raison d'être: to explore and colonize regions that were resource-rich but inhospitable, since forced labor could be ordered around the country at will (Khlevnyuk 2003a). Subsistence wages combined with the 
enforcement of effort through close supervision were supposed to promote low-cost accumulation.

At the level of the state, the continued primacy of politics over economics is shown by the fact that the NKVD-MVD did not lobby for expansion. The NKVD projected a shrinking number of Gulag inmates for the third five-year plan (1938-42), just as the first victims of Stalin's Great Terror began to flood in (Gregory 2003a). After the war, the NKVD again planned for contraction and politics again overturned this expectation (Khlevnyuk 2003a). In the late 1940s, Gulag officials proposed to release all but the most dangerous prisoners from camps (Aleksei Tikhonov 2003), but this was unacceptable to Stalin. In 1953, within three months of Stalin's death in March, MVD chief Lavrenty Beriia had released one and a half million prisoners, 60 percent of the Gulag's inmates according to a plan prepared five years earlier. In fact, elements within the MVD were increasingly alarmed by the Gulag's economic and social costs. The economic costs were reflected in its growing financial deficits; the social costs were measured by high rates of recidivism. Although the camps were supposed to segregate hardened criminals from youth offenders, the camp population was a mixing bowl and recidivism soared. The high turnover spread the culture and mores of camp life throughout society.

Why did the Gulag fail? Research on the microeconomics of the Gulag is in its infancy but early case studies show a complex learning process. The Far Eastern camps (David Nordlander 2003) show how early optimism about huge surpluses in gold mining was replaced by pessimism as output per inmate fell precipitously. The Karelian camps (Christopher Joyce 2003) show the experimental process by which the authorities learnt the scope and limits of the exploitation of forced labor. The fact that the White Sea-Baltic Canal (Mikhail Morukov 2003) was finished on time and on budget stimulated illusory expectations for the Gulag's future until its major construction flaws became apparent. The Gulag leaders willingly undertook the building of Noril'sk (Leonid Borodkin and Simon Ertz 2003) because they underestimated the risks and difficulties that would arise. The operation of Noril'sk (Ertz 2003) helped to expose illusions about the ease with which the inmates could be coerced into supplying effort without economic rewards.

By the postwar years, Gulag officials had concluded that the camps failed to generate a surplus. Labor productivity there was extremely low relative to that of free workers, while guarding detainees was very expensive; in 1950 there was one guard to ten inmates, leading to the widespread practice of "unguarded" prison contingents. Within the Gulag, prisoners formed protective networks among themselves and with the guards to cover for each other (Heinzen 2005). The arsenal of punishments was not sufficient to motivate prisoners and tradeoffs were complicated: prisoners placed on reduced rations for failing to meet work quotas were no longer able to work effectively. One of the most effective incentive systems, early release for exemplary work, deprived the Gulag of its best workers. Material incentives played an ever larger role in motivating penal labor (Borodkin and Ertz 2003, 2005; Ertz 2005). In the last years of the Gulag, there was a process of "conversion of slaves to serfs" (Khlevnyuk 2003a, p. 57); the camps increasingly paid prisoners civilian wages and the distinctions between penal and free labor became blurred.

\subsection{Coercion Failure?}

The collective farms effectively ceased to exist in the mid-1960s when the farmers were placed on fixed wages like any other employee. The Gulag was emptied of mass prisoners between 1953 and 1957. The draconian labor laws of the 1940s were rescinded in the mid-1950s. These relaxations have two possible interpretations: either the post-Stalin leadership did not have the stomach for a 
system of repression that was working or coercion was abandoned because it did not work. The new evidence supports the second interpretation, particularly the fact that the most coercive instrument, the Gulag, was dissolved by its own leaders.

In short, the initial belief that results could be obtained more cheaply by raising the penalty for failure than by increasing the reward for success appears to have been mistaken. Effective coercion requires that penalties be accurately assessed and targeted, and that the agents of repression are well informed about offenders and the costs of their crimes. It proved more difficult than expected to target penalties accurately; as a result the relationship between true effort and punishment was "noisy." The devising of an efficient coercion system is then further complicated if workers and managers respond strategically to increase the noise.

The archives show that officials had little idea whether workers were exerting full effort or not; the law could do little more than ensure that they were physically at work and did not steal too much. Agricultural controllers could order the collective farms to sow more land but could not assess whether the land was being farmed efficiently (Davies and Wheatcroft 2004). In industry, attempts to pin "normal" effort down to objective technological criteria proved fruitless; attempts to maintain effort norms when productivity should have been rising often gave rise to damaging social conflicts (Davies and Khlevnyuk 2002; Filtzer 2002).

Because the state relied on indirect indicators of effort, mistakes crept into the effort-punishment relationship. The investigation of low effort could yield an error of Type I that punished the innocent, and a Type II error that acquitted the guilty. Errors of both types appear to have been present. Numerous Type I errors are reflected in the very high rates of penalization that condemned hard workers along with ne'er-dowells, drunks, and thieves. Such a wide range of behaviors was criminalized that virtually every worker became liable to prosecution for something, including one-time and accidental violations: a broken-down commuter bus could make criminals of scores of hapless workers. Rational managers might wish to select the truly guilty for prosecution, the problem workers and repeat offenders, but the laws subjected even petty offenses to harsh penalties and managers who failed to report offenses were threatened with the same. As a result, the innocent were bundled through the courts and camps along with the guilty in extraordinarily large numbers.

Team Stalin probably knew this but did not care. In March 1937, Stalin's chief instrument of the Great Terror, Nikolai Ezhov, told his officials to expect "some innocent victims ... Better that ten innocent people should suffer than one spy get away. When you chop wood, chips fly" (Simon Sebag Montefiore 2003, p. 194). Stalin's prime minister, Molotov, (interviewed by Chuev 1991, p. 416) also cared more about condemning the guilty than acquitting the innocent, "never mind if extra heads fall."

Type II errors were also clearly numerous; this is evidenced by the fact that, although penalization rates were very high, offending rates were even higher. Filtzer (2002) used the records of eight production branch ministries in 1947 to show that almost one third of a million "labor desertions" gave rise to fewer than 55,000 convictions, for a conviction rate of 16 percent. In other words, a judicial system that was supposed to "make the chips fly" somehow failed to chop the wood. The combination of severe penalization with low conviction probability for the guilty is consistent with high-cost policing and justice administration (Gary S. Becker 1968); the high rate of conviction of innocents, however, is more properly seen as a cost of dictatorship (Simeon Djankov, Glaeser, Rafael la Porta, Florencio Lopezde-Silanes, and Shleifer 2003), in the sense that the dictator's efforts to achieve a lower rate of offending than society was willing to tolerate had highly suboptimal results. 
The effectiveness of the Politburo accumulation model rested on the dictator's ability to create a gap between the civilian wage as a "fair" return for effort, and low subsistence in the Gulag as the return to shirking, so that the difference between them was the intended punishment for shirking. Although the Gulag did not generate an internal surplus for accumulation, it could still have contributed to the surplus in the economy as a whole. The effort curve of the accumulation model will be displaced downward if civilian workers expect the Gulag wage as their punishment for low effort. But the widespread mistakes that we have described subverted this strategy: if workers expect Type I errors to prevail, they will be punished regardless of effort; if they expect to benefit from Type II errors, they can shirk without fear.

Error rates, moreover, were not exogenous. They were fashioned by the counteractions of those threatened with punishment, who could take steps to reduce their risks. Workers and managers diverted effort from production into mutual insurance: since the threat was shared among them, they could agree to cover up each other's shortcomings. The archives have added detail to the prearchival literature on concealment in the factory (Berliner 1952). Filtzer (2002) has shown that postwar managers tolerated lateness and absence to maintain goodwill, and colluded with workers to underreport such violations, while pursuing quitters who undermined morale and the factory's capacity to fulfill the plan. The rural police and courts pooled risks with the rural community in sheltering the young offenders who had deserted factories or technical schools (Kozlov 2004, vol. 1). In all these ways, mutual insurance tended to cut the individual risk of punishment. The archives also show how regional party officials defied even the most powerful central organizations to protect their own (Khlevnyuk 2004). James R. Harris (1999, pp. 156-63) has described how the Urals regional leadership formed itself into a "protected, mutually reliant" clique that fended off criticism from below and investigation from above in the mid1930 s, but was eventually wiped out in the Great Terror. Belova (2001) has shown that high-level patrons could protect the most egregious embezzlers.

Faced with widespread enforcement failures at lower levels, officials responded in two ways. First, they aimed to undermine horizontal trust by rewarding whistle blowing and informing through organized campaigns (Belova 2001). Second, Stalin forced the legal system, local party offices, and the militia to increase arrest and conviction rates or suffer penalties themselves. The most common method of forcing repression was to distribute quotas by region and profession to officials at lower levels (Kozlov 2004, vol. 1). In the Great Terror of 1937-38, local officials had to work feverishly to achieve a set number of confessions per day (A. I. Vatlin 2004). To fulfill such plans, the police officials imputed individual guilt from increasingly trivial differences in behavior. Whether or not these measures reduced the Type II errors, they seem likely to have encouraged false denunciation and confession and so added to the errors of Type I.

Team Stalin hoped, we suppose, that increased coercion would induce agents to take a lower wage without withdrawing effort, making coercion effectively costless. The evidence suggests that, in practice, those threatened with punishment raised the chance of escaping detection (a Type II error) through mutual insurance, but this diverted effort from production. At the same time, successful collusion against Type I errors (false accusation) combined with the increased chance of a Type II error to blunt the effect of penalization on the reservation wage. Finally, the heavy direct costs of the repressive apparatus must have further reduced the net payoff from coercion.

We have only one empirical study of the aggregate effects of the terror on industrial production (Barbara G. Katz 1975), which 
attributes the 1937 slowdown in industrial growth to political repression. New archival studies show the disastrous effects of the Great Terror on important Gulag operations (Ertz 2003). Finally, the archives have shown that Soviet leaders themselves saw a direct connection between the terror and falling productivity (Davies 2004): the terror eliminated a generation of skilled and knowledgeable managers and technical staff, worsened labor discipline, and damaged effort.

\subsection{Sharing the Surplus}

Whatever the mechanism, Stalin's economic policy certainly generated a substantial increase in the excess of output over consumption for use in investment, defense, or other public spending. But surpluses attract rent-seekers. To what extent did Stalin have to share the proceeds with others as the price of his power? This is a question that could not be asked before the archives were available. Although the archives are now open, definitive answers remain elusive.

The archives show that Stalin presided over a "nested" dictatorship (Lazarev and Gregory 2002; Gregory and Markevich 2002; Gregory 2004) in which power was delegated from one vertical level to the next so that each organization duplicated the administrative control structures of its superior. Each principal in turn acted as the agent of a higher principal until the top where the great dictator ruled alone. This was also a complex hierarchy with nodes from which organizations stemmed with partly complementary, partly overlapping functions. The dictator ruled by delegation, so under him there ruled many smaller dictators who exercised unconstrained power within their specialized fiefs that Stalin personally allocated to them.

Recent studies of the Soviet nomenklatura under Stalin, which comprised up to the order of a million posts (Lewin 2003; Khlevnyuk 2003b), show how power cascaded downward through branching networks of agents that fractionalized the "aggregate" nomenklatura into many little nomenklaturas each dependent on an intermediate boss. With delegation and fractionalization, these would form natural market places for the exchange of gifts and favors for loyalty in which distributional conflicts and deals took place.

In the 1930s, investment was the largest single use of Stalin's rent. It is not easy to tell whether he distributed it primarily to share rents or to generate growth. In principle, the rent shared would have been the excess of outlays in a given use over those which a growth-maximizing dictator would have allocated. Even if rent-sharing took place, however, it would have been rationalized under the official guise of advancing growth, and the dictator's most loyal agents already occupied the key positions most likely to receive investment.

Recent case studies throw light on the motivation behind particular transactions. In the late 1920s, the Politburo and its agent, Gosplan, fought against regional rent seeking, accusing "irresponsible" regions of "self serving projections based on local interest, lack of objectivity, and inexact calculations that undermine the very foundations of planning" (Gregory 2004, p. 80). Stalin resisted fierce regional lobbying in the second half of the 1920 s, rejecting projects such as the Dneprstroi metallurgy complex on the grounds that there were better uses of the funds (Lih, Naumov, and Khlevnyuk 1995). Gosplan's resistance evaporated with the 1929 purge of those who argued for realistic planning. Regional leaders descended on Moscow with grandiose investment plans (Harris 1999). Eventually Stalin set up institutional barriers to this kind of behavior: regional party leaders required official permission to come to Moscow and enterprises were prohibited from maintaining representative agents in Moscow (Khlevnyuk 2004).

Stalin's advocacy of superindustrialization from 1928 on promoted his power as well as his long-run rents. He gained allies among regional leaders by espousing a program that 
promised unlimited funding. Stalin's appointments diary is full of meetings with regional leaders who made the pilgrimage to Stalin to seek favors. Stalin was uncharacteristically concerned in 1931-32 that his home republic Georgia was "on the verge of hunger" and of "bread riots," while he made "feigning hunger" a counterrevolutionary offense in other republics (Getty and Naumov 1999, p. 69). Lazarev and Gregory (2003) have analyzed the dictator's distribution of motor vehicles, the scarcest capital good of the time, from his own reserve funds. The strong econometric results show that Team Stalin allocated vehicles for political gain and that economic considerations were not significant. 13

Stalin needed a growing military and industrial base and could not have allowed rent seeking to randomize investment beyond a point. Stalin opposed the "unnecessary spreading of investment" that resulted from industrial and regional authorities' competing bids to start up favored projects (cited by Davies and Khlevnyuk 1997, p. 41). A first-hand account shows Stalin advocating investment rationality at a meeting in 1947: "The plan is very inflated and is not within our capacity. We should give money only to projects that can be put into commission, and not spread it out among many projects. They are building all kinds of nonsense in new, unpopulated areas and they are spending a lot of money. It is necessary to expand old factories. Our dear fantasists design only

\footnotetext{
${ }^{13}$ This study is based on full data on requests for motor vehicles from the dictator's reserve fund in 1932 and 1933, a process that was quite separate from the wholesale allocation of motor vehicles through ministries and regional authorities. The researchers had each request, the cases made for the allocation, letters of support, and the eventual outcome. The final decisions were made by a high-level Politburo commission headed by Molotov. The researchers coded the cases made for the vehicle allocation as "economic," for example a note from Gosplan explaining why this allocation was vital to fulfill the plan, or "political," for example support from a political patron. In the regressions, only the political variables were significant in explaining approvals. Economic variables were insignificant and also had the wrong signs.
}

new factories and inflate construction" (cited by Khlevnyuk 2000). In the early 1930s, the Politburo, in a rare show of opposition to Stalin, delayed the Baltic-White Sea Canal until Stalin reduced its cost by proposing the use of “cheap" Gulag labor (Morukov 2003).

The Red Army provides a case study in Stalin's relationship with a powerful special interest. Sokolov (2005) has shown that the demands of the armed forces were significant in Stalin's turn to forced collectivization and industrialization in 1929-30, and the military leaders themselves supported his resort to a command economy to bring these things about. Stalin quickly moved to raise military spending in secret in 1931 (Davies 1993). On the other hand, he kept professional soldiers out of the Politburo. He also consistently resisted the attempts of military modernizers, such as Marshal M. N. Tukhachevskii, to use plans for a mechanized mass army to justify a military role in managing the defense industry (Lennart Samuelson 2000). Evidently alert to the danger that the armed forces could become just another special interest, Stalin encouraged rivalry and tension between the army and the industrialists who might otherwise have formed natural allies (Gregory 2003b; Harrison 2003b). While Stalin lived, therefore, there was no emergence of a "military-industrial complex," whatever may be said of the Soviet Union under his successors.

Similarly, there is evidence of rent seeking in military R\&D but no evidence that Stalin or his subordinates wanted it that way (Harrison 2003a, forthcoming-b). He punished rent seeking where he suspected it, and this helped to make the intermediaries that he charged with funding this work keen to get results.

\section{Money, Prices, and the Seller's Market}

A third set of issues addressed by archival research considers how plans and commands are nested with markets and money, how markets work, and how contracts are enforced in the context of a seller's market. 
These issues connect literatures that are not often linked, dealing with markets and hierarchies, contracts and enforcement (Avner Greif 1993, 1994, 2000; Greif, Paul Milgrom, and Barry R. Weingast 1995), and the soft budget constraint (Kornai 1980; Maskin 1996, 1999; Kornai, Maskin, and Roland 2003).

\subsection{The Soft Budget Constraint}

Kornai (1980) developed the concept of the soft budget constraint to explain shortages and sellers' markets in Soviet type economies; he attributed the soft constraint to the state's paternalistic domination and its desire to insure enterprises against failure. The resulting moral hazard damaged firms' incentive to economize on inputs and created an insatiable hunger for resources that was eventually transmitted to permanent shortages and queues in retail markets. Kornai (1980) maintained that such shortages could not be eliminated by price flexibility. An early critic, Stanislaw Gomulka (1985), suggested that price rigidity must be a necessary condition of shortage, specifically that input prices must be less negotiable than firms' budgets, but there did not appear to be a convincing explanation of why the state should cap input prices. Others have attempted to deduce the soft budget constraint from the formal rules and incentives arising from specific institutions, rather than from Kornai's political negotiation process; for example, $\mathrm{M}$. Dewatripont and Maskin (1995) suggested that the softening agent is the sunk costs that arise when there is sequential monitoring of long-lived enterprises and their financing is centralized. Underlying all these variants is a problem of dynamic commitment (Mark E. Schaffer 1989): the state does not intend to support loss-making ventures but is unable to commit itself not to after the event, and those responsible for the losses anticipate this beforehand.

In contrast, Shleifer and Vishny (1992) and Wintrobe (1998) departed fundamentally from Kornai, questioning how excess demand could be transmitted from firms to the retail market and arguing that shortage could be explained more parsimoniously by firms' withholding supplies and pushing prices down in order to collect bribes from consumers.

The literature thus offers a range of hypotheses for archival research. Kornai would look for a political decision by Team Stalin to tolerate loss-making activities so as to exploit the economy for political goals. Dewatripont and Maskin would look for the rules and incentives that made funding principals prefer to tolerate losses. Gomulka and others would expect to see the price controls of which shortage is a by-product, while Shleifer and Vishny suggest that shortage is the intentional creation of rent-seeking producers who restrict output and lobby for low prices.

Archival investigations have shown that all the theoretical explanations of the soft budget constraint have some merit; they do not support the Shleifer-Vishny critique. The documents of the formative years tell Kornai's story of a mobilizing state overriding the market to gain discretionary power over resources. $\frac{14}{14}$ In the 1920 s, the ruling Bolsheviks allowed industry to go over from self-financing to a regime of price controls and subsidies for the sake of its plans for industrial and military mobilization; military-industrial interests and military lobbying were more important in this process than was previously recognized (Sokolov 2005). The trusts that were later transformed into ministries were already shifting funds from profitable to loss-making enterprises in the mid-1920s (Gregory and Tikhonov 2000). As the state won control of agriculture through collectivization and the first five year plan was enacted, soft budget constraints were extended to industry and investment as a whole (Harris 1999). Specific legislative

\footnotetext{
${ }^{14}$ Kornai ought to have been right; he had the advantage over others of witnessing the formative years of the Hungarian planning system as an insider.
} 
attempts to harden budgets were quickly abandoned (Gregory and Tikhonov 2000). These episodes show that budget constraints became soft through a direct exercise of power that changed the relationship between the state and the economy. To the dictatorship, the loss of financial credibility was a price worth paying for the freedom to its pursue wider goals.

More detailed case studies have also shown the value of institutions-based theorizing. Long-lived $R \& D$ projects in defense industry, for example, were funded and monitored in installments. The resulting sunk costs made the authorities ready to refinance projects that they would not have financed initially with complete foresight (Harrison 2003a). Even in this case, however, the documents reveal an intrinsic element of negotiation that is not captured by a model based on formal rules alone. Funding principals could not or did not wish to commit to explicit rules. They understood the games that unscrupulous agents could play with such rules and they sought to regain financial control in two ways. First, they cut funding back from time to time in ways that were to some extent arbitrary. Second, even if establishments were never closed for making a loss, they could be put under new management and the old management could be demoted and punished individually. For self-protection, agents built mutual insurance networks and also engaged in cutthroat rivalry to protect funding. Thus, well after the formative years, the softening of budget constraints cannot be understood without close attention to political processes of vertical bargaining and horizontal rivalry and collusion.

Does the story of the soft budget constraint stand up as an explanation of Soviet retail shortage? The transmission mechanism, doubted by Shleifer and Vishny (1992) and Wintrobe (1998), has been substantiated from unique access to the post-Stalin Gosplan archives by Byung-Yeon Kim (1997, 1999, 2002). According to Kornai (1980, pp. 486-88), the soft budget constraint would lead to retail shortage if firms used claims on inputs to "siphon" general-purpose commodities intended for the retail market back into production. Kim showed that siphoning really did drain off resources that should have been available for private consumption, that actual private saving was persistently higher than suggested by published budget surveys, and that significant private saving was forced by firms' siphoning activity as a result.

Budget constraints were soft but not limitless; what were the limits on softness? Kornai (1980, p. 211-14) defined three "tolerance limits" on the state's readiness to accommodate inefficient behavior: foreign currency, social unrest, and administrative complaints. The view of Stalin's economic policy set out above confirms the importance of all three. Stalin personally kept an iron grip on foreign exchange. The unrest associated with consumption shortfalls is represented by the disorder constraint in figure 1. Finally, the Politburo carefully monitored the flow of complaints up the vertical hierarchy for signs of general worker discontent.

\subsection{Money and Prices in the Seller's Market}

In theory, money was relatively unimportant in the Soviet command system. Firms' soft budget constraints created seller's markets, the so-called "dictatorship of the seller." Prices were ineffective in incentivizing producers and signaling allocative needs (Kornai 1980). Instead, the planners' "visible hand" was supposed to direct allocation of producer goods at controlled prices (Nove 1961; Ellman 1972, 1979; Gregory and Stuart 1974). The banks supplied money and credit to "follow" physical plans; under early Soviet rule this was called "planned automatism" (Gregory and Tikhonov 2000). Money merely enabled planners to practice "control by the ruble," monitoring financial flows to detect departures from physical directives. The money stock was supposed to be strictly segregated into bank money for interfirm transactions and cash money for wage payments. Given that firms could use money 
only for planned purposes, there would be little incentive for them to acquire additional holdings. The state budget mainly provided a façade behind which the authorities could divert resources from profit-making enterprises to loss-makers and the military (Igor Birman 1981).

A major surprise from the archives is that money played a much larger role than we expected. Allocation actually began not with physical supply plans but with nominal budgetary assignments to investment and other government uses such as military orders. The Politburo gave much more time and energy to how rubles would be spent than to consideration of the "control figures" for output in physical units (Davies 2001a; Gregory 2001; Davies, Ilič, and Khlevnyuk 2004).

Budget outlays usually came first because broad-brush supply plans could not fix the detailed assortment of physical products or their final uses. Plans in rubles of output were then calculated at "fixed" plan prices. Plan targets had to be fixed in rubles because most producers supplied many products and output was too heterogeneous to be planned any other way. Supply quotas binding on individual ministries and enterprises were also denominated in rubles (Harrison 1998). While the government might announce a plan target for steel tonnage, the directive plan for the enterprise was in rubles; interagency contracts were supposed to link the two, but were usually incomplete or hard to enforce, even in the defense industry where compliance was monitored intently. Markevich and Harrison (forthcoming) report the case of an aircraft factory in 1934 where the same managers, reprimanded for poor-quality work, were rewarded days later for fulfilling the plan-in rubles, of course.

Stalin-era plans were too aggregated to tie producers to particular products or users to particular suppliers; this suited both ministries and planners. Planners could not disaggregate plans efficiently, and preferred the responsibility for disaggregation and subcontracting to lie at the ministerial level or below. Ministries also liked this arrangement because it freed them to decide how best to fulfill aggregate ministerial output in plan rubles.

Final allocations of products were achieved through contracting between ministries, ministry main administrations, and enterprises. Research on the late Soviet-era economy showed that this contracting process was relatively decentralized (Heidi Kroll 1986, 1988). In the Stalin era, supply planning set limits on this process but the limits were broad. The ministry's annual or quarterly supply plan was only the first salvo in the "battle for the plan," in which users of intermediate goods entered bids with producers for the contracts needed for their own plans (Harrison and Nikolai Simonov 2000; Gregory and Markevich 2002). At this point, command-economy allocation became a market-like contracting process; official retail markets that traded state goods openly at state prices and retraded them under the counter at a premium were just at one extreme of a continuum of market-oriented activities that even included bizarre activities such as home production of automobiles (Lazarev and Gregory 2002).

Decentralized contracting generated a degree of price flexibility, and this tells us much about the motivations, resources, and constraints of the agents involved. By devising legal and illegal ways to bid up contract prices, suppliers could fulfill both plans and contracts with less effort and more financial gain. According to the stereotype, prices were supposed to be fixed from above on the basis of initial costs plus an allowance for overhead and taxes. Longstanding empirical concerns about official price indexes (Colin Clark 1939; Alexander Gerschenkron 1947; Bergson 1947, 1953, 1987; Peter J. D. Wiles 1982; Hanson 1984), including the exploitation of new products specifically to free the enterprise from fixed plan prices (Berliner 1976; Harrison 1998), suggested that the fixed-price assumption might oversimplify. Kornai (1980, p. 363) specifically noted the 
interest of the firm in higher prices. Nonetheless, standard accounts of Soviet allocation took it for granted that the firm was a price taker (Nove 1958; Edward Ames 1965; Michael Manove 1971; Richard E. Ericson, 1983, 1984; Stephen M. Goldfeld and Richard E. Quandt, 1988, 1990; Shleifer and Vishny, 1992).

The archives show that price-setting was one of the most important activities of Soviet firms (Harrison 1998); producers' pressure on prices was relentlessly upward, not downward as Shleifer and Vishny (1992) predicted. Actual transaction prices were negotiated between buyers and sellers during "contract campaigns" loosely managed from above (Harrison and Simonov 2000; Gregory 2004). A memo described the consequences of failure to pay an "illegal" high price: "If you don't want to pay, we'll keep this in mind when we consider your next order" (cited in Gregory 2004, p. 220). Official prices were supposed to be used in more important transactions but official price handbooks were often incomplete, lagged behind new products, or were ignored. The mammoth metals administration of the ministry of heavy industry employed only three persons in its pricing department, which set the official prices of metallurgical products (Gregory 2004). The defense ministry was particularly vulnerable to inflationary pricing because of the rapidity with which its product requirements were changing. Military buyers complained of prices based on "how much it costs whether the result of correct work or poor management." (Gregory 2004, p. 220). Defense suppliers withheld information about costs on the grounds that it was too sensitive to entrust to the defense ministry. They would delay settlement and hold out for higher prices and illegal advance payments before agreeing to terms (Harrison and Simonov 2000).

Figure 2 illustrates the resulting bargain. The plan of military orders obliged industry to deliver a volume of output $Q^{*}$ at a preset price $P^{*}$. Industry's problem was that to produce $Q^{*}$ cost effort; it would be more advan- tageous if the defense ministry could be persuaded to settle for a smaller real quantity, say $Q^{\prime}$ in the figure, at some higher price level $P^{\prime}$ along a unit-elastic curve through $Q^{*}, P^{*}$. It did this by reporting higher costs relative to the true effort of producing them, and by introducing new products at a higher ratio of reported cost-to-effort, i.e., by simulating productive effort.

Price renegotiation was costly, however. At some margin, the simulation of productive effort became as costly as productive effort itself. Planners monitored the prices of existing products although they could do little to control the prices of new ones (Harrison 1998). Faced with price gouging, a powerful buyer like the army could complain through the defense minister to the Politburo on which he sat (Davies and Harrison 1997). Less powerful customers could and did complain frequently to the state arbitration commission (Gregory 2004) provided they were willing to risk disrupting good relations with suppliers. It is noteworthy that the Soviet authorities applied the term "signalization" to the scarcity information forthcoming from the arbitration courts.

The widespread evidence on illegal price increases raises a number of questions. If enterprises had soft budget constraints, why did they make the effort to push up prices and incur the legal risks rather than wait passively for an automatic subsidy? The answer is that subsidies were not automatic and softening budget constraints took effort. The enterprise had to equate the effort costs of overcoming resistance at several margins represented by the ministry which could switch funding from profit to loss makers, the budgetary and credit authorities, and a buyer that had to contend with its own budget constraint. Overcoming the resistance of the buyer enabled one enterprise that faced more resistance from superiors to pass its problem on to another that faced less. This phenomenon expressed itself in illegal but persistent interenterprise payment arrears, 


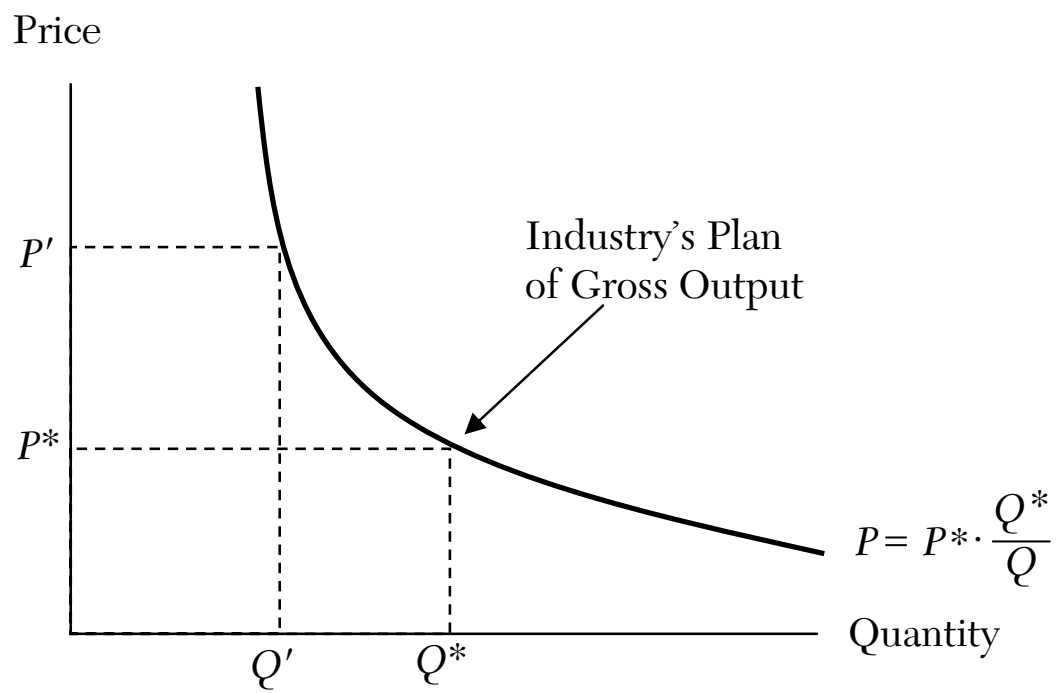

Source: for the full reasoning underlying this figure, see Gregory 2003b and Harrison and Kim 2004.

Figure 2. Price Renegotiation

ultimately made good by the state bank as lender of last resort (Gregory and Tikhonov 2000).

Since producers had to spend effort and incur risks to extract it from superiors and buyers, it follows that money was not free. Despite the supposed firewall between traceable bank money and anonymous cash, increases in official credits were in fact accompanied by increases in cash holdings (Gregory and Tikhonov 2000). The importance of money is underscored by Stalin's auditors who uncovered numerous cases of fraud and embezzlement that resulted in the accumulation of caches of illegal money (Belova 2001). Apparently, not all scarcity markups were lost in lobbying costs or favors to third parties.

Unauthorized cash did not necessarily go to line private pockets. Harrison and Kim (forthcoming) argue that the main purpose of hidden inflation and siphoning was to relieve effort. Thus Soviet corruption differed from a conventional picture of bribe-taking for personal enrichment: managers extracted side payments from buyers more usually to engage in siphoning and fulfill the plan, so that the proceeds of corruption were recycled into production. Planners could shift the purposes of corruption from embezzlement to siphoning up to a point by raising plan tension, although this helped the planner more than the consumer. It follows, Harrison and Kim suggest, that the lower plan tension under Brezhnev (Schroeder 1985) may have encouraged disloyal or privately motivated embezzlement.

\subsection{Commands, Contracts, and Enforcement}

To persist, hierarchies and markets must both evolve ways to motivate repeated participation. According to Greif (2000), people continue to participate in an institution when it is in their interest to do, conditional upon their expectation that others have made the same calculation. When transactions are 
sequential and the completion of a contract rests on advances by one agent to another, the institutional equilibrium requires an enforcement mechanism to prevent cheating by some that makes abstention by others their best option.

The command system combined hierarchy with elements of horizontal dealing; the archives show that the dictator gave his tacit approval to this. When hierarchies and markets coexist, they must find a joint equilibrium in the sense that changes in the marginal returns are likely to induce agents to reallocate effort from one to the other. An increase in market returns, or a reduction in the power of principals, would shift resources out of the vertical hierarchy into unofficial horizontal dealing. Thus vertical enforcement relies on the ability of principals to reward loyalty and punish disloyalty and so offset the potential gains from horizontal exchange.

The problem of horizontal relationships was particularly acute given the persistence of outside options for agents in the hierarchy. Stalin may have aspired to monopolize the economy into a corporation that was integrated on both horizontal and vertical lines, but this aspiration was not and could not be realized. Bureaucrats could choose to deal privately with each other rather than through superiors. There was a thriving labor market that moved workers from enterprise to enterprise, even when coercion was at its most intense. Everyone could turn either to legal or illegal commodity markets. Outside the country, citizens could sell secrets to a foreign business or power or defect to a foreign country. In this general sense, the final collapse of the Soviet command system was a failure of vertical enforcement and compliance (Harrison 2002).

According to Greif (2000), the "fundamental problem of exchange" is the possibility of horizontal cheating in markets. In hierarchies, there is a parallel fundamental problem of command (Harrison 2005): an agent may exploit the principal by shirking or stealing. The returns to stealing, however, are reduced if what is stolen cannot be sold, and this is more likely when market transactions cannot rely on the law and depend on private enforcement alone. Therefore the enforceability of vertical commands is likely to vary inversely with that of private contracts. Stalin made use of this trade-off by privileging socialist property over private property and enacting harsher penalties for theft from the state than from fellow citizens (Gorlizki 2001b).

When agents resorted to unauthorized business contacts, the ability to complete transactions depended on a business reputation for plain dealing and keeping one's word. Belova $(2001,2005)$ has analyzed the "relational" contracting system that arose where unauthorized contracts were costly to enforce or unenforceable in the courts: agreements rested on a handshake and were enabled by personal contact and friendship which alone could overcome the culture of low trust.

Even loyal agents, however, had to engage in some unauthorized market trading to fulfill plans that were incompletely provided for. Despite the threat to dictatorial power of unauthorized horizontal trade, the clear message of the industrial archives is that a "good" manager was expected to get the job done by all means necessary and at any price [liuboi tsenoi]. The minister of heavy industry, for example, bluntly relayed this message to his managers: "We will not listen to those people who say our materials have not been delivered, but we say that a good manager, a good shop director, a good master technician knows how to organize things and produce the required results" (cited by Gregory 2004, p. 164). In short, the command system relied on loyal agents' unauthorized horizontal dealing on behalf of the plan, despite the fact that disloyal trading detracted from the dictator's goals.

Principals could not necessarily distinguish the unofficial deals that agents made to fulfill the plan from those that lined their pockets. 
A study of the last Soviet-era anticorruption drive, based on rare access to the post-Stalin judicial archives (Luc Duhamel 2004), suggests that disloyal agents would always claim loyal motivation, and sometimes the investigators did not want to know because they had a political agenda. Belova (2001) argues that, in the Stalin era, principals insured against disloyal corruption by tolerating horizontal networks while restricting their scope. As a result, horizontal reputation could only accumulate within small groups. This limited private exchange by reducing the efficiency of relational contracting.

\section{Efficiency, Growth, and Reform}

The debate over the feasibility of central planning occupied leading economic thinkers for a century. Barone's "Ministry of Production in the Collectivist State" (1908, reprinted 1935) was followed by Mises' "Economic Calculation in the Socialist Commonwealth" (1920, reprinted 1935) and Hayek's many writings on the information problems of a nonmarket economy (1935, $1937,1940,1945)$. Bergson's two surveys $(1966,1967)$ remain authoritative accounts of the controversy. Following the Great Depression and World War II, some economists argued that socialized investment could offset high private discount rates, relieve bottlenecks, or eliminate the business cycle. Even Bergson (1948, reprinted 1966, p. 230) suggested that "in a highly dynamic economy, a centralist allocation of investment might lead to fewer and smaller errors than a competitive allocation." Despite the collapse of the Soviet Union and China's gradual conversion to a market economy, the debate over the merits of socialism continues (Don Lavoie 1985; James Junker 1992; Pranab K. Bardhan and John E. Roemer 1993; Shleifer and Vishny 1994; Peter J. Boettke 2001).

\subsection{Efficient Choices}

The archives illustrate the Hayekian problem: the decisionmakers could not gather or process the information required to make efficient decisions. The information and decision overload came in part from the Politburo's inability to distinguish the important from the trivial. Decision-making resources were scarce; in the 1930s Stalin and the Politburo made between 2,300 and 3,500 recorded decisions per year (Gregory 2004). Much time was spent on trivia, from individual permits for foreign travel to locations for monuments and vegetable and metro prices in Moscow. Issues defined as major were delegated to ad hoc commissions with very high transactions costs: for example, a special commission made up of the chairman of Gosplan, who doubled as deputy prime minister, the head of Gosplan's fuel commission, timber ministry officials, and regional officials had to meet to decide on a requested cut in timber supplies equal to a fraction of one percent of total output (Rees 1997b).

While Team Stalin labored over details that were often trivial, it delegated major decisions of project choice by default. While the Politburo required major projects to be approved on official "title lists," the producers themselves largely determined how to spend their investment rubles. The title lists lacked cost estimates in many cases despite the efforts of Gosplan, Gosbank, and the finance ministry to enforce formal rules on cost discipline (Belova and Gregory 2002).

When information was not simply lacking, it was limited by opportunism. Investment contractors opportunistically refused to provide information; they complained, for example, that cost audits would delay urgent tasks or compromise state security (Harrison and Simonov 2000; Harrison 2004). More generally, those who possessed valuable information tried to monopolize it and shared it only when they could extract a rent in exchange.

Information problems led to catastrophic investment blunders such as the Baltic-White Sea Canal, which was too shallow for effective use, and the Baikal-Amur 
Mainline which remained unfinished for forty years (Khlevnyuk 2001b; Joyce 2003). Investment projects initiated without feasibility studies and budgets proved unexpectedly difficult to finish. Increases in unfinished construction rose sharply in crisis years such as 1931-32 and 1936-37 when the proportion of gross investment that merely added to work in progress rose above 15 percent of the total (Harrison 1994). Market economies are not immune to investment blunders, but no one has yet compared unfinished construction in Soviettype and market systems. One reason, we speculate, is that statistical offices do not see the problem of unfinished construction under market arrangements as worth monitoring.

Not all high-level decisions were inefficient or irrational. Had this been the case, the economy could hardly have grown, survived the onslaught of Germany in World War II, or created modern nuclear and aerospace industries. In some respects, Stalin's economic decision making did better than would have been predicted by those who regarded socialist planning as infeasible. This mixed evaluation was already present in the literature before the archives. Studies confirmed low rates of technological improvement and diffusion (Antony C. Sutton 1968, 1971, 1973; Berliner 1976; Amann, Julian Cooper, and Davies 1977; Bergson 1978; Ronald Amann and Cooper 1982, 1986; Hanson and Keith Pavitt 1987) due to the lack of incentives for producers to adopt new technologies and planning "from the achieved level."15 But the same system also gave rise to some spectacular firsts and near firsts, especially in the technologies of defense and heavy industry. While

\footnotetext{
${ }^{15}$ Russians used this expression to convey a rule-ofthumb that sets the next target equal to the previous level achieved plus an arbitrary increment. Birman (1978) described the practice and Martin L. Weitzman (1980) and Michael Keren (1982) formalized it in the concept of the ratchet effect.
}

it is true that invention was not typically matched by innovation (Amann 1986), the record of invention was still remarkable for a relatively poor country.

Archives and interviews have unraveled the decisions that established new atomic and aerospace industries after World War II (David Holloway 1994; Simonov 2000; Harrison 2000). Notably, decisionmakers tended to reserve their scarce attention and available funding for military priorities, and the decisive information that signaled where resources should go came from the monitoring of progress abroad.

Previous insider accounts of Soviet inventions were highly selective; they concentrated on success stories and gave self-serving interpretations of what motivated successful inventors and designers. The archives record the failures as well as the successes, and Harrison (2000, 2003a, forthcoming) formulates a framework for Soviet invention as an economic activity: the initial offer of funding in a field such as aviation created a "market for inventions" that attracted designers and projects in large numbers. As one would expect, the designers tended to be heterogeneous in talent and motivation; on a first pass, it would seem that they were motivated by a varying mix of intellectual curiosity, the expected reputational rewards for breakthrough projects, and the funding that could be consumed before a project that failed was terminated. Notably, the distribution of scientific reputation did not rely on the state for enforcement; it was conferred, at least in part, by the community of specialists. At the same time, the prolonged refinancing of unsuccessful projects, for example for steam-powered bombers, suggests that the uncertainty and information biases surrounding $R \& D$ permitted adverse selection and provided fertile soil for rent seeking.

In contrast, there was no reputation to be gained from replicating a technology "not invented here." A variety of studies (Holloway 1994; Nataliia Lebina 2000; 
Harrison 2000) have shown that, while Stalin regarded the fact that a technology had already been developed elsewhere as a positive signal, Soviet nuclear, missile, and aircraft designers disliked being ordered to follow in others' footsteps without imposing their own stamp; this sometimes resulted in backward steps. A case study of aeroengine development (Harrison forthcoming) shows that, when a breakthrough was still anticipated, the inventors were willing to work for relatively modest material rewards that were spread around fairly evenly because the major prize for which they competed was the reputation for priority in an invention. After the breakthrough, when a reputation for priority could no longer be won, the same people required monetary rewards that were many times higher than before and much more regressive to engage in the development work.

\subsection{Planning by Feel}

The concept of planning by feel is illustrated by an anecdote: in Moscow in 1981, a Soviet historian told one of the authors that the great skill of Gosplan director, Nikolai Voznesenskii, as an economic planner was that "he could feel the disproportions in the economy through his fingertips." The archives reveal that this was not just a clever remark. Overwhelmed by unreliable information and computational constraints, the planners had to turn to intuition and rules-of-thumb based on experience. Some, like Voznesenskii, appeared to have better intuition than others.

Planners were supposed to distribute materials according to engineering norms, but the first allocations took place before norms were compiled (Gregory and Markevich 2002; Gregory 2004). Supply agencies used intuition, trial and error, and "historical experience." According to one supply official: "We give 100 units to one branch administration, 90 to another. In the next quarter we'll do the reverse and see what happens. You see, we do this on the basis of feel; there is no explanation" (Gregory and Markevich 2002, pp. 805-06). According to another: "Our problem is that we can't really check orders and are not able to check them. ... We operate partially on the basis of historical material-we are supposed to give so and so much in this quarter, and at the same time you are supposed to give us this much." (cited by Gregory 2004, p. 172). Workers' piece-rate norms were also set from the achieved level or just "by eye" (Davies and Khlevnyuk 2002 , p. 877). Mises (1949, reprinted 1998, p. 696) predicted that in the absence of economic calculation planning would be reduced to "groping in the dark." This, then is how they groped.

Ministry and supply officials understood that enterprises, being "greedy opportunists," demanded "too much." When the minister of heavy industry asked: "Tell us please how our enterprises received 50 percent of supplies they requested and fulfilled their production programs 100 percent?" the response was: "In July, I told my people to prepare a report about the fulfillment of plans for individual branches. I then began to edit these reports and saw that the production programs had been fulfilled 102 percent but only 40 percent of supplies had been received. I believed there was something left over from the previous year. I looked into the report for the previous year-again 103 percent and supplies only 40 percent. I couldn't look at the year previous to that because I could not find it" (cited by Gregory 2004, p. 172). When the first vehicles began rolling off assembly lines in 1933, the producer demanded the entire year's output for its own use (Lazarev and Gregory 2002, pp. 329-30); Gosplan retaliated by ordering customers to "liquidate sloppy and unjustified requests."

Without norms and with "sloppy" material requests, initial allocations of materials and equipment were arbitrary but reached equilibrium with surprising speed. As the distribution of domestically produced vehicles 
began in 1932, only fifteen percent of orders were filled, rising to fifty percent by the fourth quarter of 1934 and to almost ninety percent by the first quarter of 1937 (Lazarev and Gregory 2002). This rapid convergence is not explained by the increase in supply alone. Enterprises, government agencies, and individuals had a virtually unlimited notional demand. Their effective demand, however, was limited by the expectation that this year's allocation would start from last year's; this illustrates planning from the achieved level. Once initial allocations were fixed, a basic distributional consensus quickly emerged. ${ }^{16}$ Given the difficulty of balancing supplies with notional demands for commodities in short supply, transaction costs were limited by adapting effective demands to the existing distribution. While limiting transaction costs, therefore, planning from the achieved level also limited structural adaptation. Even worse, and contrary to what has been argued (Manove 1971), it did not necessarily eliminate large initial errors since it induced expectations to converge on initial allocations however inefficient.

\subsection{Obstacles to Reform}

In the early 1960s, Soviet officials began to discuss openly whether it was possible to nest the informational and incentive advantages of markets within the hierarchical structures of the command economy under the banner of socialist economic "reforms." The archives show, however, that they had been pursuing this quest behind closed doors from the early 1930s. The need to reform became evident to insiders from the start, refuting the textbook stereotype of a planning system that

\footnotetext{
${ }^{16}$ From a starting point of violent disagreement over the distribution of vehicles, the correlation coefficients among the distribution plans prepared by the three agencies involved-producer, Gosplan, and the responsible Politburo commission-rose to above 95 percent by the third quarter of 1933 despite their different agendas (Lazarev and Gregory 2002, p. 336). The initial endowment was essentially random; planning from the achieved level then locked users into an "endowment" that drifted incrementally in subsequent periods.
}

worked well while the Soviet economy was less developed, and needed reform only after industrial modernization.

The story that Davies (1996) tells is roughly as follows. The difficulties of supply planning in 1929 and 1930 quickly convinced Stalin's industry chief, Ordzhonikidze, that detailed interplant transactions should be decentralized. By 1931 he had become a keen advocate of cost accounting and the idea that, given harder budget constraints, enterprises could subcontract for supplies in a decentralized way without planners. His economic mechanism to enforce budget constraints and make managers automatically accountable for their own choices was clearly enunciated: "If you supply [the buyer] everything on time in accordance with the contract, you will get the appropriate payment . . . If you don't meet the obligations that you have taken on, [the buyer] won't pay you, the bank won't pay you on [the buyer's] behalf any more, and you, dear comrade, will have to have a very hard think about how to pay your wages, how to carry on the work at your factory" (cited by Davies 1996, p. 12: emphasis added). Some of Orzhonikidze's officials went still further, advocating the hardening of investment budget constraints by financing it on the basis of repayable loans, and a considerable degree of price liberalization.

Three barriers to reform reinforced each other. First, Stalin and Molotov regarded the retention of money and the return to cost accounting after the chaos of 1929-30 as essentially temporary expedients. They could have no intellectual sympathy for hard budget constraints, particularly for investment. Second, these reservations appeared justified by events. At the end of 1932, Ordzhonikidze unexpectedly cancelled centralized equipment supply plans for the iron, steel, coal, and oil industries for 1933, and told producers and users to sort it out themselves. "This sudden freedom caused panic" (Davies 1996, p. 269). On the one side, equipment suppliers had no instructions on 
how to ration supplies; in law they were criminally liable if they refused an order. On the other hand, the equipment purchasers, freed from all restraint, tried to place orders that were vastly inflated, but succeeded in placing only a small fraction. Still committed to the reform, Ordzhonikidze turned the balancing of supply and demand over to a conference of industry representatives in Moscow. But, in the spring of 1933, the Politburo instigated the dismissal of the most radical reformists, leaving Ordzhonikidze frustrated and humiliated.

A third reason for reform failure lay underneath the other two: "With the high level of investment which obtained in 1932, such a reformed system was quite impracticable, and it may have been entirely incompatible with Soviet economic objectives" (Davies 1996, p. 267). If so, then Ordzhonikidze was at fault in failing to understand this.

The archives reveal that the reform stalemate of the post-Stalin years dates to the beginning of the Stalin era. Agents could not trust principals not to make mistakes, pointed to stupid, contradictory, changing orders and excessive meddling, and demanded greater autonomy. But when they won autonomy they behaved opportunistically and sought rents rather than profits. Principals could not trust agents to behave altruistically and eventually had to intervene to curb rent-seeking and restore order. Agents behaved the way they did because they rationally expected principals to intervene. Living in a nested dictatorship, they saw no role for the dictators at every level other than to dictate. As long as they expected this there was little point in looking for financial savings that were could be confiscated at any time. Better to go on hoarding, concealing, and bargaining.

\section{What's New?}

What do recent studies of the Soviet archives offer to the political economy of command systems and dictatorship?
First, the archives show a powerful but fallible dictatorship comprised of Stalin and his Politburo immersed in the detail of economic decisions. They guided the general direction of the economy by infrequent major decisions that set aggregate investment, which they poorly controlled, while reserving the right to make unlimited detailed interventions in current operations. The command system that resulted featured extreme centralization and the priority of vertical over horizontal relationships. Minor decisions were delegated from top to bottom through a hierarchy of "nested" dictatorship. Formal rules were avoided in favor of ad hoc decision making. A compliant planning board was disengaged from responsibility for detailed allocation to guarantee its loyalty; the dictator was particularly loathe to delegate economic decisions to politically unreliable technocrats. As a result, delegation did not work well: subordinates funneled even trivial decisions upwards to limit their own exposure, placing a "dictator's curse" of excessive administrative burdens on their superiors at each levels, most heavily on Stalin himself.

Second, in the context of the great increase in investment in the 1930s, the record of decision making in the Politburo supports the hypothesis of a dictator interested in investment, growth, and efficiency, while balancing these against other objectives such as retaining loyalty and avoiding revolts. His management of investment required unflagging attention to the effect of consumption on worker incentives. The fear of consumption falling to a point where worker unrest would spread contributes to explaining the cyclical behavior of investment.

Third, the archival literature sheds considerable light on limits on the power of the dictator to extract a surplus through largescale coercion. Frightened and intimidated people still did not do as they were told; rather, they invested all the more in horizontal transactions that protected them from repression and diverted effort from planned goals. One of the most surprising results of 
research on the Gulag is that its own administrators regarded it as an economic and social failure, and that its supreme administrator was the major force pushing for its liquidation shortly after Stalin's death. Coercion was scaled down not because new, more principled leaders came to power but because the old unprincipled leaders knew it did not work. This insight raises an interesting problem: if, as many have argued, the Soviet-type system cannot function without coercion, what should it do when coercion also does not work?

Fourth, having created a surplus, Stalin had to prevent vigorous rent seeking from politicizing its distribution. Special branch and regional interests formed immediately within the dictator's own circle, leaving Stalin and a few associates to battle for what they viewed as encompassing interests. Even with access to virtually all official documents, we cannot measure the degree to which the top leadership allocated investment to purchase loyalty rather than for economic rationality. Stalin may have been more tolerant of rent seeking in earlier periods when his regime was still fragile. Political motives may help explain the allocation of regional investment and motor vehicles in the early 1930s, but Stalin seems to have stamped on rent seekers when he detected them in military matters.

Fifth, the industrial archives contribute to debate about whether there existed anything that we should call "planning." All so-called operational plans of the Stalin era were provisional and subject to change by any superior. Faced with provisional plans and the prospect of endless interventions, enterprises and ministries sometimes refused to commit to plans; some enterprises operated without "plans" for years. Resource allocation by intervention rather than by plan is consistent with the dictator's aversion to formal rules. A "final" plan represents a formal rule that could prevent superiors from exercising "resource mobility." The chaos of ad hoc interventions then explains the attraction of planning from the achieved level, a customary rule which introduced order at the expense of freezing initial allocations and inhibiting adaptation.

Sixth, the dictator struck a deal with functional agencies, such as the State Planning Commission, various control commissions, and, above all, the secret police that he would not hold them responsible for final results if they provided honest information. But the information available to the Politburo, although far greater in quantity, suffered from the same flaws as that which was published. Most information was provided by the producers themselves, who had incentives to exaggerate inputs needs and to understate capacity. Even the secret police had an incentive to exaggerate dangers to enhance their claim on resources. The dictator's honest information brokers could at best perform infrequent audits. This information flowed with difficulty because processing capacity was limited, and because information was monopolized and traded for private gain rather than freely shared. Good information was so hard to get that planning relied more on intuition than on the "scientific" methodology of Soviet handbooks. Huge blunders resulted. Where decisions have appeared wise in retrospect, for example, in defense technology, they often relied on information from abroad and mechanisms such as scientific reputation that did not depend on state enforcement.

Seventh, the soft budget constraint originated historically in the Stalinist political commitment to mobilization and was perpetuated by centralized institutions that prevented ex ante commitments to financial discipline from being implemented after the event. Notably, subsidies were not extended automatically to loss makers without lobbying investments, which helps explain the unexpected interest of producers in higher prices and money, including traceable bank money. The archives provide no support for the proposition that Soviet enterprises sought lower prices to maximize bribes; rather enterprises took advantage of 
the seller's markets to extract higher prices even from influential buyers such as the defense ministry. Corruption existed but the archives leave the impression that most illegal siphoning was done to fulfill the plan, not for private gain.

Eighth, the pervasiveness of markets in which even high-level administrators (such as ministers) participated reflects the dilemma of the dictator who requires subordinates to solve their own problems "at any price," including by recourse to informal markets, while the networks that formed as a result had the potential to undermine dictatorial power. These markets did not work well, were severely circumscribed, and relied heavily on relational enforcement; private contracts were not legally enforceable and reputations could spread only within narrow circles.

Ninth and finally, the flaws of the planned economy became immediately apparent to its leaders, prompting reform proposals to increase enterprise independence. But the results of partial reforms were if anything worse than those of the unreformed system. Enterprises might prefer to circumvent the apparently arbitrary, even stupid interventions of superiors; but the same enterprises, unconstrained by the discipline of market forces, could not be trusted with independence. The resulting stalemate continued to the last days of the Soviet Union.

\section{REFERENCES}

Acemoglu, Daron, and James A. Robinson. 2000. "Political Losers as a Barrier to Economic Development." American Economic Review, 90(2): 126-30.

Akerlof, George A. 1984. "Gift Exchange and Efficiency-Wage Theory: Four Views." American Economic Review, 74(2): 79-83.

Akerlof, George A., and Janet L. Yellen. 1990. "The Fair Wage-Effort Hypothesis and Unemployment." Quarterly Journal of Economics, 105(2): 255-83.

Amann, Ronald. 1986. "Technical Progress and Soviet Economic Development: Setting the Scene," in Technical Progress and Soviet Economic Development. Ronald Amann and Julian Cooper, eds. Oxford: Blackwell, 5-30.

Amann, Ronald, and Julian Cooper, eds. 1982. Industrial Innovation in the Soviet Union. New
Haven: Yale University Press.

Amann, Ronald, and Julian Cooper, eds. 1986. Technical Progress and Soviet Economic Development. Oxford: Blackwell.

Amann, Ronald, Julian Cooper, and R. W. Davies, eds. 1977. The Technological Level of Soviet Industry. New Haven: Yale University Press.

Ames, Edward. 1965. Soviet Economic Processes. Homewood, Ill.: Irwin.

Bardhan, Pranab K., and John E. Roemer. 1993. Market Socialism: The Current Debate. New York: Oxford University Press.

Barone, Enrico. 1908/1935. "Il Ministro della Produzione nello Stato Collettivista," translated as "The Ministry of Production in the Collectivistic State," in Collectivist Economic Planning: Critical Studies on the Possibility of Socialism. F. A. Hayek, ed. London: Routledge, 245-90.

Becker, Gary S. 1968. "Crime and Punishment: An Economic Approach." Journal of Political Economy, 76(2): 169-217.

Belova, Eugenia. 2001. "Economic Crime and Punishment," in Behind the Façade of Stalin's Command Economy: Evidence from the State and Party Archives. Paul R. Gregory, ed. Stanford: Hoover Institution Press, 131-58.

Belova, Eugenia. 2005. "Legal Contract Enforcement in the Soviet Economy." Comparative Economic Studies, 47(2): 387-401.

Belova, Eugenia, and Paul Gregory. 2002. "Dictator, Loyal, and Opportunistic Agents: The Soviet Archives on Creating the Soviet Economic System." Public Choice, 113(3-4): 265-86.

Berelovich, A., ed. 2000. Sovetskaia derevnia glazami VChK-OGPU-NKVD, 2: 1923-1929. Moscow: ROSSPEN.

Berelovich, A., and V. P. Danilov, eds. 1998. Sovetskaia derevnia glazami VChK-OGPU-NKVD, 1: 1918-1922. Moscow: ROSSPEN.

Bergson, Abram. 1947. "A Problem in Soviet Statistics." Review of Economics and Statistics, 29(4): 234-42.

Bergson, Abram. 1953. "Reliability and Usability of Soviet Statistics: A Summary Appraisal." American Statistician, 7(3): 13-16.

Bergson, Abram. 1961. The Real National Income of Soviet Russia Since 1928. Cambridge: Harvard University Press.

Bergson, Abram. 1964. The Economics of Soviet Planning. New Haven: Yale University Press.

Bergson, Abram. 1966. Essays in Normative Economics. Cambridge: Harvard University Press.

Bergson, Abram. 1978. Productivity and the Social System: The USSR and the West. Cambridge: Harvard University Press.

Bergson, Abram. 1987. "On Soviet Real Investment Growth." Soviet Studies, 39(3): 406-24.

Berliner, Joseph S. 1952. "The Informal Organization of the Soviet Firm." Quarterly Journal of Economics, 66(3): 342-65.

Berliner, Joseph S. 1957. Factory and Manager in the USSR. Cambridge: Harvard University Press.

Berliner, Joseph S. 1976. The Innovation Decision in Soviet Industry. Cambridge: MIT Press. 
Birman, Igor. 1978. "From the Achieved Level." Soviet Studies, 30(2): 153-72.

Birman, Igor. 1981. Secret Incomes of the Soviet State Budget. London: Nijhoff.

Blanchard, Olivier, and Michael Kremer. 1997. "Disorganization." Quarterly Journal of Economics, 112(4): 1091-1126.

Boettke, Peter J. 2001. Calculation and Coordination: Essays on Socialism and Transitional Political Economy. London: Routledge.

Bornstein, Morris. 1985. "Improving the Soviet Economic Mechanism." Soviet Studies, 37(1): 1-30.

Borodkin, Leonid, and Simon Ertz. 2003. "Coercion versus Motivation: Forced Labor in Norilsk," in The Economics of Forced Labor: The Soviet Gulag. Paul R. Gregory and Valery Lazarev, eds. Stanford: Hoover Institution Press, 75-104.

Borodkin, Leonid, and Simon Ertz. 2005. "Forced Labor and the Need for Motivation: Wages and Bonuses in the Stalinist Camp System." Comparative Economic Studies, 47(2): 418-36.

Carr, Edward H., and R. W. Davies. 1969. A History of Soviet Russia 3: Foundations of a Planned Economy, 1926-1929, Part 1. London: Macmillan.

Chuev, F. I. 1991. Sto sorok besed s Molotovym. Moscow: Terra.

Chuev, F. I. 1992. Tak govoril Kaganovich. Moscow: Otechestvo.

Clark, Colin. 1939. A Critique of Russian Statistics. London: Macmillan.

Conquest, Robert. 1967. Industrial Workers in the USSR. London: The Bodley Head.

Conquest, Robert. 1987. The Harvest of Sorrow: Soviet Collectivization and the Terror-Famine. Oxford: Oxford University Press.

Danilov, Viktor P., Roberta T. Manning, and Lynne Viola, eds. 1999. Tragediia sovetskoi derevni. Kollektivizatsiia $i$ raskulachivanie. 1927-1939. Dokumenty i materialy. Moscow: ROSSPEN.

Davies, R. W. 1980a. The Industrialization of Soviet Russia, 1: The Socialist Offensive: The Collectivization of Soviet Agriculture, 1929-1930. Basingstoke: Macmillan.

Davies, R. W. 1980b. The Industrialization of Soviet Russia, 2: The Soviet Collective Farm, 1929-1930. Basingstoke: Macmillan.

Davies, R. W. 1989a. The Industrialization of Soviet Russia, 3: The Soviet Economy in Turmoil, 1929-1930. Basingstoke: Macmillan.

Davies, R. W. 1989b. Soviet History in the Gorbachev Revolution. Basingstoke: Macmillan.

Davies, R. W. 1993. "Soviet Military Expenditure and the Armaments Industry, 1929-33: A Reconsideration." Europe-Asia Studies, 45(4): 577-608.

Davies, R. W. 1996. The Industrialization of Soviet Russia, 4: Crisis and Progress in the Soviet Economy, 1931-1933. Basingstoke: Macmillan.

Davies, R. W. 1997. Soviet History in the Yeltsin Era. Basingstoke: Macmillan.

Davies, R. W. 2001a. "Making Economic Policy," in Behind the Façade of Stalin's Command Economy: Evidence from the State and Party Archives. Paul R.
Gregory, ed. Stanford: Hoover Institution Press, 61-80.

Davies, R. W. 2001b. "Why Was There a Soviet Investment Cycle in 1933-37?" University of Warwick. PERSA Working Paper No. 16.

Davies, R. W. 2003. "The Archives and the Stalinist Economy." University of Warwick. PERSA Working Paper No. 27.

Davies, R. W. 2004. "The Soviet Economy and the Launching of the Great Terror." University of Warwick. PERSA Working Paper No. 29.

Davies, R. W., and Mark Harrison. 1997. "The Soviet Military-Economic Effort under the Second FiveYear Plan 1933-1937." Europe-Asia Studies, 49(3): 369-406.

Davies, R. W., Melanie Ilič, and Oleg Khlevnyuk. 2004. "The Politburo and Economic Policy-Making," in The Nature of Stalin's Dictatorship: The Politburo, 1924-1953. E. A. Rees, ed. Basingstoke: Palgrave, 108-34.

Davies, R. W., and Oleg Khlevnyuk. 1997. "Gosplan," in Decision-Making in the Stalinist Command Economy, 1932-37. E. A. Rees, ed. Basingstoke and London: Macmillan, 32-66.

Davies, R. W., and Oleg Khlevnyuk. 1999. "The End of Rationing in the Soviet Union, 1934-1935." Europe-Asia Studies, 51(4): 557-610.

Davies, R. W., and Oleg Khlevnyuk. 2002. "Stakhanovism and the Soviet Economy." Europe-Asia Studies, 54(6): 867-903.

Davies, R. W., Oleg V. Khlevnyuk, E. A. Rees, Liudmilla P. Kosheleva, and Larisa A. Rogovaia, eds. 2003. The Stalin-Kaganovich Correspondence, 1931-36. New Haven: Yale University Press.

Davies, R. W., Mark B. Tauger, and Stephen G. Wheatcroft. 1995. "Stalin, Grain Stocks and the Famine of 1932-1933." Slavic Review, 54(3): 642-57.

Davies, R. W. and Stephen G. Wheatcroft. 2004. The Industrialization of Soviet Russia, 5: The Years of Hunger: Soviet Agriculture, 1931-1933. Basingstoke: Palgrave.

Dewatripont, Mathias, and Eric Maskin. 1995. "Credit and Efficiency in Centralized and Decentralized Economies." Review of Economic Studies, 62(4): 541-55.

Djankov, Simeon, Edward Glaeser, Rafael la Porta, Florencio Lopez-de-Silanes, and Andrei Shleifer. 2003. "The New Comparative Economics." Journal of Comparative Economics, 31(4): 595-619.

Duhamel, Luc. 2004. "The Last Campaign Against Corruption in Soviet Moscow." Europe-Asia Studies, 56(2): 187-212.

Easterly, William, and Stanley Fischer. 1995. "The Soviet Economic Decline." World Bank Economic Review, 9(3): 341-71.

Ellman, Michael. 1972. Soviet Planning Today. Cambridge: Cambridge University Press.

Ellman, Michael. 1975. "Did the Agricultural Surplus Provide the Resources for the Increase in Investment in the USSR during the First Five Year Plan?" Economic Journal, 85(340): 844-63.

Ellman, Michael. 1979. Socialist Planning. Cambridge: Cambridge University Press. 
Ellman, Michael. 2000. "The 1947 Soviet Famine and the Entitlement Approach to Famines." Cambridge Journal of Economics, 24(5): 603-30.

Ericson, Richard E. 1983. "On an Allocative Role of the Soviet Second Economy," in Marxism, Central Planning, and the Soviet Economy: Economic Essays in Honor of Alexander Erlich. Padma Desai, ed. Cambridge: MIT Press, 110-32.

Ericson, Richard E. 1984. "The 'Second Economy' and Resource Allocation under Central Planning." Journal of Comparative Economics, 8(1): 1-24.

Erlich, Alexander. 1960. The Soviet Industrialization Debate, 1924-1928. Cambridge: Harvard University Press.

Ertz, Simon, 2003. "Building Norilsk," in The Economics of Forced Labor: The Soviet Gulag. Paul R. Gregory and Valary Lazarev, eds. Stanford: Hoover Institution Press, 127-50.

Ertz, Simon. 2005. "Trading Effort for Freedom: Workday Credits in the Soviet Camp System." Comparative Economic Studies, 47(2): 476-91.

Filtzer, Don. 2002. Soviet Workers and Late Stalinism: Labour and the Restoration of the Stalinist System after World War II. Cambridge: Cambridge University Press.

Fitzpatrick, Sheila. 1999. Everyday Stalinism: Ordinary Life in Extraordinary Times: Soviet Russia in the 1930s. Oxford: Oxford University Press.

Ganelin, R. S., ed. 2004. Istoriia sozdaniia $i$ razvitiia oboronnopromyshlennogo kompleksa Rossii i SSSR. 1901-1963 gg. Dokumenty i materialy, 1: Voennaia promyshlennost' Rossii $v$ nachale XX veka (1901-1918 gg.). Moscow: Novyi Khronograf.

Gerschenkron, Alexander. 1947. "The Soviet Indices of Industrial Production." Review of Economics and Statistics, 29(4): 217-26.

Getty, J. Arch, and Oleg Naumov. 1999. The Road to Terror: Stalin and the Self-Destruction of the Bolsheviks, 1932-1939. New Haven: Yale University Press.

Glaeser, Edward L., Rafael La Porta, Florencio Lopezde-Silanes, and Andrei Shleifer. 2004. "Do Institutions Cause Growth?" NBER Working Paper 10568.

Goldfeld, Stephen M., and Richard E. Quandt. 1988. "Budget Constraints, Bailouts, and the Firm under Central Planning." Journal of Comparative Economics, 12(4): 502-20.

Goldfeld, Stephen M., and Richard E. Quandt. 1990. "Output Targets, the Soft Budget Constraint and the Firm under Central Planning." Journal of Economic Behavior and Organization, 14(2): 205-22.

Gomulka, Stanislaw. 1985. "Kornai's Soft Budget Constraint and the Shortage Phenemenon: A Criticism and Restatement." Economics of Planning, 19(1): 1-11.

Gorlizki, Yoram. 2001a. "Stalin's Cabinet: The Politburo and Decision-Making in the Post-War Years." Europe-Asia Studies, 53(2): 291-312.

Gorlizki, Yoram. 2001b. "Theft Under Stalin: A Property Rights Analysis." University of Warwick. PERSA Working Paper No. 10.

Gorlizki, Yoram. 2002. "Ordinary Stalinism: The
Council of Ministers and the Soviet Neopatrimonial State, 1946-1953." Journal of Modern History, 74(4): 699-736.

Gorlizki, Yoram, and Oleg Khlevnyuk. 2004. Cold Peace: Stalin and the Soviet Ruling Circle, 1945-1953. New York: Oxford University Press.

Granick, David. 1954. Management of the Industrial Firm in the USSR. New York: Columbia University Press.

Granick, David. 1987. Job Rights in the Soviet Union: Their Consequences. New York: Cambridge University Press.

Gregory, Paul R. 2001. "The Dictator's Orders," in Behind the Façade of Stalin's Command Economy: Evidence from the State and Party Archives. Paul Gregory, ed. Stanford: Hoover Institution Press, 11-33.

Gregory, Paul R. 2003a. "An Introduction to the Economics of the Gulag," in The Economics of Forced Labor: The Soviet Gulag. Paul R. Gregory and Valery Lazarev, eds. Stanford: Hoover Institution Press, 1-21.

Gregory, Paul R. 2003b. "Soviet Defence Puzzles: Archives, Strategy, and Underfulfillment." EuropeAsia Studies, 55(6): 923-38.

Gregory, Paul R. 2004. The Political Economy of Stalinism: Evidence from the Soviet Secret Archives. New York: Cambridge.

Gregory, Paul R., and Andrei Markevich. 2002. "Creating Soviet Industry: The House That Stalin Built." Slavic Review, 61(4): 787-814.

Gregory, Paul R., and Robert C. Stuart. 1974. Soviet Economic Structure and Performance. New York: Harper and Row.

Gregory, Paul R., and Aleksei Tikhonov. 2000. "Central Planning and Unintended Consequences: Creating the Soviet Financial System, 1930-1939." Journal of Economic History, 60(4): 1017-40.

Greif, Avner. 1993. "Contract Enforceability and Economic Institutions in Early Trade: The Maghribi Traders' Coalition." American Economic Review, 83(3): 525-48.

Greif, Avner. 1994. "Cultural Beliefs and the Organization of Society: A Historical and Theoretical Reflection on Collectivist and Individualist Societies." Journal of Political Economy, 102(5): 912-50.

Greif, Avner. 2000. “The Fundamental Problem of Exchange: A Research Agenda in Historical Institutional Analysis." European Review of Economic History, 4(3): 251-84.

Greif, Avner, Paul Milgrom, and Barry R. Weingast. 1995. "Coordination, Commitment, and Enforcement: The Case of the Merchant Guild." Journal of Political Economy, 102(4): 745-76.

Grossman, Gregory. 1953. "Scarce Capital and Soviet Doctrine." Quarterly Journal of Economics, 67(3): 311-43.

Hanson, Philip. 1983. "Success Indicators Revisited: The July 1979 Decree on Planning and Management." Soviet Studies, 35(1): 1-13.

Hanson, Philip. 1984. "The CIA, the TsSU, and the Real Growth of Soviet Investment." Soviet Studies, 86(4): 571-81. 
Hanson, Philip, and Keith Pavitt. 1987. The Comparative Economics of Research, Development and Innovation in East and West: A Survey. Chur, Switzerland: Harwood.

Harris, James R. 1999. The Great Urals: Regionalism and the Evolution of the Soviet System. Ithaca: Cornell University Press.

Harrison, Mark. 1994. "National Income," in The Economic Transformation of the Soviet Union, 1913-45. R. W. Davies, Mark Harrison, and S. G. Wheatcroft, eds. Cambridge: Cambridge University Press, 38-56.

Harrison, Mark. 1998. "Prices, Planners, and Producers: An Agency Problem in Soviet Industry, 1928-1950." Journal of Economic History, 58(4): 1032-62.

Harrison, Mark. 2000. "New Postwar Branches (1): Rocketry," in The Soviet Defence-Industry Complex from Stalin to Khruschev. John Barber and Mark Harrison, eds. Basingstoke: Macmillan, 118-49.

Harrison, Mark. 2002. "Coercion, Compliance, and the Collapse of the Soviet Command Economy." Economic History Review, 55(3): 397-433.

Harrison, Mark. 2003a. "The Political Economy of a Soviet Military R\&D Failure: Steam Power for Aviation, 1932 to 1939." Journal of Economic History, 63(1): 178-212.

Harrison, Mark. 2003b. "Soviet Industry and the Red Army under Stalin: A Military-Industrial Complex?" Les Cahiers du Monde Russe, 44(2-3): 323-42.

Harrison, Mark. 2004. "Why Secrets? The Uses of Secrecy in Stalin's Command Economy." University of Warwick. PERSA Working Paper No. 34.

Harrison, Mark. 2005. "The Fundamental Problem of Command: Plan and Compliance in a Partially Centralized Economy." Comparative Economic Studies, 47(2): 296-314.

Harrison, Mark. Forthcoming. "A Soviet Quasi-Market for Inventions: Jet Propulsion, 1932 to 1946." Research in Economic History.

Harrison, Mark, and Byung-Yeon Kim. Forthcoming. "Plans, Prices, and Corruption: The Soviet Firm Under Partial Centralization, 1930 to 1990." Journal of Economic History.

Harrison, Mark, and Nikolai Simonov. 2000. "Voenpriemka: Prices, Costs, and Quality Assurance in Interwar Defence Industry," in The Soviet Defence-Industry Complex From Stalin to Khrushchev. John Barber and Mark Harrison, eds. Basingstoke: Macmillan, 223-45.

Hayek, F. A. 1937. "Economics and Knowledge." Economica, 4(13): 33-54.

Hayek, F. A. 1940. "Socialist Calculation: The Competitive 'Solution'." Economica, 7(26): 125-49.

Hayek, F. A. 1944. The Road to Serfdom. Chicago: University of Chicago Press.

Hayek, F. A. 1945. "The Use of Knowledge in Society," American Economic Review, 35(4): 519-30.

Heinzen, James W. 2004. Inventing a Soviet Countryside: State Power and the Transformation of Rural Russia, 1917-1929. Pittsburgh: University of Pittsburgh Press.

Heinzen, James W. 2005. "Corruption in the Gulag: Dilemmas of Officials and Prisoners." Comparative
Economic Studies, 47(2): 456-75.

Hessler, Julie. 2004. A Social History of Soviet Trade: Trade Policy, Retail Practices, and Consumption, 1917-1953. Princeton: Princeton University Press.

Holloway, David. 1994. Stalin and the Bomb: The Soviet Union and Atomic Energy, 1939-1956. New Haven: Yale University Press.

Jasny, Naum. 1949. The Socialized Agriculture of the USSR: Plans and Performance. Stanford: Stanford University Press.

Joyce, Christopher. 2003. "The Gulag in Karelia: 1929-1941," in The Economics of Forced Labor: The Soviet Gulag. Paul R. Gregory and Valery Lazarev, eds. Stanford: Hoover Institution Press, 163-88.

Junker, James. 1992. Socialism Revised and Modernized: The Case for Pragmatic Market Socialism. New York: Praeger.

Katz, Barbara G. 1975. "Purges and Production: Soviet Economic Growth, 1928-1940." Journal of Economic History, 35(3): 567-90.

Keren, Michael. 1982. "The Ministry, Plan Changes, and the Ratchet in Planning." Journal of Comparative Economics, 6(4): 327-42.

Khlevnyuk, Oleg V. 1993. Stalin i Ordzhonikidze. Konflikty v Politburo v 30-e gody. Moscow: Rossiia molodaia.

Khlevnyuk, Oleg V. 1995. "The Objectives of the Great Terror, 1937-38," in Soviet History, 1917-1953: Essays in Honour of R. W. Davies. J. M. Cooper, Maureen Perrie, and E. A. Rees, eds. New York: St. Martin's Press, 158-76.

Khlevnyuk, Oleg V. 1996. Politburo. Mekhanizmy politchecheskoi vlasti $v$ 1930-e gody. Moscow: ROSSPEN.

Khlevnyuk, Oleg V. 2000. "Sovetskaia ekonomicheskaia politika na rubezhe 40-50 godov i delo Gosplana." Paper presented at a conference on "Stalin's Politburo," Florence, Italy, March 29-31, 2000.

Khlevnyuk, Oleg V. 2001a. "Stalinism and the Stalin Period after the 'Archival Revolution'." Kritika, 2(2): 319-28.

Khlevnyuk, Oleg V. 2001b. "The Economy of the Gulag," in Behind the Façade of Stalin's Command Economy: Evidence from the State and Party Archives. Paul R. Gregory, ed. Stanford: Hoover Institution Press, 111-30.

Khlevnyuk, Oleg V. 2003a. "The Economy of the OGPU, NKVD, and MVD of the USSR, 1930-1953: The Scale, Structure, and Trends of Development," in The Economics of Forced Labor: The Soviet Gulag. Paul R. Gregory and Valery Lazarev, eds. Stanford: Hoover Institution Press, 43-66.

Khlevnyuk, Oleg V. 2003b. "Sistema tsentr-regiony v 1930-1950-e gody. Predposylki politizatsii nomenklatury." Les Cahiers du Monde Russe, 44(2-3): 253-68.

Khlevnyuk, Oleg V. 2004. "Vzaimootnesheniia tsentra i regionov v 30-e gg." Vestnik Moskovskogo Universiteta, 21(3): 79-98.

Khlevnyuk, Oleg V., R. W. Davies, L. P. Kosheleva, E. A. Rees, and L. A. Rogovaia, eds. 2001. Stalin $i$ Kaganovich. Perepiska. 1931-1936 gg. Moscow: ROSSPEN. 
Khlevnyuk, Oleg V., Yoram Gorlizki, L. P. Kosheleva, A. I. Miniuk, M. I. Prozumenshchikov, L. A. Rogovaia, and S. V. Somonova, eds. 2002. Politburo TsK VPK $(b)$ $i$ Sovet Ministrov SSSR. 1945-1953. Moscow: ROSSPEN.

Khlevnyuk, Oleg V., A. V. Kvashonkin, L. P. Kosheleva, and L. A. Rogovaia, eds. 1995. Stalinskoe Politburo v 30-e gody. Sbornik dokumentov. Moscow: AIRO-XX.

Kim, Byung-Yeon. 1997. "Soviet Household Saving Function." Economics of Planning, 30(2-3): 181-203.

Kim, Byung-Yeon. 1999. "The Income, Savings, and Monetary Overhang of Soviet Households." Journal of Comparative Economics, 27(4): 644-68.

Kim, Byung-Yeon. 2002. "Causes of Repressed Inflation in the Soviet Consumer Market, 1965-1989: Retail Price Subsidies, the Siphoning Effect, and the Budget Deficit." Economic History Review, 55(1): 105-27.

Kontorovich, Vladimir. 1986. "Discipline and Growth in the Soviet Economy." Problems of Communism, 34(6): 18-31.

Kontorovich, Vladimir. 1988. "Lessons of the 1965 Soviet Economic Reform." Soviet Studies, 40(2): 308-16.

Kornai, János. 1980. The Economics of Shortage. Amsterdam: North-Holland.

Kornai, János. 1992. The Socialist System: The Political Economy of Communism. Princeton: Princeton University Press.

Kornai, János, Eric Maskin, and Gerard Roland. 2003. "Understanding the Soft Budget Constraint." Journal of Economic Literature, 41(4): 1095-1136.

Kozlov, V. P., ed. 2004. Istoriia Stalinskogo Gulaga. Moscow: ROSSPEN.

Kroll, Heidi. 1986. "Decentralization and Precontract Disputes in Soviet Industry." Soviet Economy, 2(1): 51-71.

Kroll, Heidi. 1988. "The Role of Contracts in the Soviet Economy." Soviet Studies, 40(3): 349-66.

Kuromiya, Hiroaki. 1988. Stalin's Industrial Revolution: Politics and Workers, 1928-1932. Cambridge: Cambridge University Press.

Kuznets, Simon. 1963. "A Comparative Appraisal," in Economic Trends in the Soviet Union. Abram Bergson and Simon Kuznets, eds. Cambridge: Harvard University Press, 333-82.

Lange, Oskar. 1964. On the Economic Theory of Socialism. New York: McGraw-Hill.

Lavoie, Don. 1985. Rivalry and Central Planning: The Socialist Calculation Debate Reconsidered. Cambridge: Cambridge University Press.

Lazarev, Valery. 2005. "Promotion Incentives and Support for the Soviet Regime." Comparative Economic Studies, 47(2): 346-63.

Lazarev, Valery, and Paul R. Gregory. 2002. "The Wheels of a Command Economy: Allocating Soviet Vehicles." Economic History Review, 55(2): 324-48.

Lazarev, Valery, and Paul R. Gregory. 2003. "Commissars and Cars: A Case Study in the Political Economy of Dictatorship." Journal of Comparative Economics, 31(1): 1-19.

Lebina, Nataliia. 2000. "The Defence-Industry Complex in Leningrad (2): The Postwar Uranium Industry," in The Soviet Defence-Industry Complex from Stalin to Khruschev. John Barber and Mark Harrison, eds. Basingstoke: Macmillan, 184-94.

Lewin, Moshe. 1968. Russian Peasants and Soviet Power: A Study of Collectivization. London: Allen and Unwin.

Lewin, Moshe. 2003. "Rebuilding the Soviet Nomenklaturas, 1945-1948." Les Cahiers du Monde Russe, 44(2-3): 219-52.

Lih, Lars, Oleg Naumov, and Oleg Khlevnyuk. 1995. Stalin's Letters to Molotov, 1925-1936. New Haven: Yale University Press.

Manning, Roberta T. 1993. "The Soviet Economic Crisis of 1936-1940 and the Great Purges," in Stalinist Terror: New Perspectives. J. Arch Getty and Roberta T. Manning, eds. Cambridge: Cambridge University Press, 116-41.

Manove, Michael. 1971. "A Model of Soviet-Type Economic Planning." American Economic Review, 61(3): 390-406.

Markevich, Andrei. 2003. "Was the Soviet Economy Planned? Planning in the People's Commissariats in the 1930s." University of Warwick. PERSA Working Paper No. 25.

Markevich, Andrei. 2005. "Soviet Planning Archives: The Files that Bergson Could Not See." Comparative Economic Studies, 47(2): 364-86.

Markevich, Andrei, and Mark Harrison. Forthcoming. "Quality, Experience, and Monopoly: The Soviet Market for Weapons under Stalin." Economic History Review.

Maskin, Eric S. 1996. "Theories of the Soft BudgetConstraint." Japan and the World Economy, 8(2): 125-33.

Maskin, Eric S. 1999. "Recent Theoretical Work on the Soft Budget Constraint." American Economic Review, 89(2): 421-25.

Millar, James R. 1974. "Mass Collectivization and the Contribution of Soviet Agriculture to the First FiveYear Plan: A Review Article." Slavic Review, 33(4): 750-66.

von Mises, Ludwig. 1920/1935. "Die Wirtschaftsrechnung im sozialistischen Gemeinwesen," translated in Collectivist Economic Planning: Critical Studies on the Possibility of Socialism. F. A. Hayek, ed. London: Routledge, 87-130.

von Mises, Ludwig. 1949/1998. Human Action: A Treatise on Economics. Auburn, Ala.: Ludwig von Mises Institute.

Montefiore, Simon Sebag. 2003. Stalin: The Court of the Red Tsar. London: Weidenfeld and Nicolson.

Morukov, Mikhail. 2003. "The White Sea-Baltic Canal," in The Economics of Forced Labor: The Soviet Gulag. Paul R. Gregory and Valery Lazarev, eds. Stanford: Hoover Institution Press, 151-62.

Nordlander, David. 2003. "Magadan and the Economic History of Dalstroi in the 1930s," in The Economics of Forced Labor: The Soviet Gulag. Paul R. Gregory and Valery Lazarev, eds. Stanford: Hoover Institution Press, 105-25.

Nove, Alec. 1958. "The Problem of 'Success Indicators' in Soviet Industry.” Economica, 25(97): 1-13.

Nove, Alec. 1961. The Soviet Economy. London: Allen and Unwin. 
Nove, Alec. 1969. An Economic History of the USSR. London: Allen and Unwin.

Nove, Alec. 1977. The Soviet Economic System. London: Allen and Unwin.

Ofer, Gur. 1987. "Soviet Economic Growth: 1928-1985." Journal of Economic Literature 25(4): 1767-1833.

Olson, Mancur. 1993. "Dictatorship, Democracy, and Development." American Political Science Review, 87(3): 567-76.

Osokina, Elena. 2001. Our Daily Bread: Socialist Distribution and the Art of Survival in Stalin's Russia, 1927-1941. Armonk, NY: M. E. Sharpe.

Podkaminer, Leon. 1989. “Theory of Investment Cycles in the Centrally Planned Economies: An Economic Interpretation." Forschungberichte no. 158. Wiener Institut für Internationaler Wirtschaftsvergleiche.

Rees, E. A., ed. 1997a. Decision-Making in the Stalinist Economy, 1932-37. Basingstoke: Macmillan.

Rees, E. A. 1997b. “The People's Commissariat of the Timber Industry," in Decision-Making in the Stalinist Economy, 1932-37. E. A. Rees, ed. Basingstoke: Macmillan, 124-49.

Rees, E. A. 2001. "Leaders and their Institutions," in Behind the Façade of Stalin's Command Economy: Evidence from the State and Party Archives. Paul R. Gregory, ed. Stanford: Hoover Institution Press, 35-60.

Rees, E. A., ed. 2004. The Nature of Stalin's Dictatorship: The Politburo, 1924-1953. Basingstoke: Palgrave.

Rees, E. A., and D. H. Watson. 1997. "Politburo and Sovnarkom," in Decision-Making in the Stalinist Command Economy, 1932-37. E. A. Rees, ed. Basingstoke: Macmillan, 9-31.

Rittersporn, Gábor T. 2001. "New Horizons: Conceptualizing the Soviet 1930s." Kritika, 2(2): 307-18.

Rutland, Peter. 1985. The Myth of the Plan. LaSalle, IL: Open Court.

Samuelson, Lennart. 2000. Plans for Stalin's War Machine: Tukhachevskii and Military-Economic Planning, 1925-41. London: Macmillan.

Schaffer, Mark E. 1989. "The Credible-Commitment Problem in the Center-Enterprise Relationship." Journal of Comparative Economics, 13(3): 359-82.

Schelling, Thomas C. 1960. The Strategy of Conflict. Oxford: Oxford University Press.

Schrettl, Wolfram. 1982. Consumption, Effort, and Growth in Soviet-Type Economies: A Theoretical Analysis. Ann Arbor: University Microfilms International.

Schrettl, Wolfram. 1984. "Anspruchdenken, Leistungbereitschaft und Wirtschaftszyklen," in Wachstumsverlangsamung und Konjunkturzyklen in Unterschiedlichen Wirtschaftssystemen. A. Schuller, ed. Berlin: Duncker and Humblot, 153-91.

Schroeder, Gertrude E. 1973. "Recent Developments in Soviet Planning and Incentives," in Soviet Economic Prospects for the Seventies. U.S. Congress Joint Economic Committee. Washington, D.C.: U.S. Government Printing Office, 11-38.

Schroeder, Gertrude E. 1979. "The Soviet Economy on a Treadmill of 'Reforms',' in Soviet Economy in a Time of Change. U.S. Congress Joint Economic Committee. Washington, D.C.: U.S. Government Printing Office, 312-40.

Schroeder, Gertrude E. 1982. "Soviet Economic 'Reform' Decrees: More Steps on the Treadmill,' in Soviet Economy in the 1980s: Problems and Prospects. U.S. Congress Joint Economic Committee. Washington, D.C.: U.S. Government Printing Office, 65-88.

Schroeder, Gertrude E. 1985. "The Slowdown in Soviet Industry, 1976-1982." Soviet Economy, 1(1): 42-74.

Sen, Amartya K. 1981. Poverty and Famines: An Essay on Entitlement and Deprivation. Oxford: Oxford University Press.

Shleifer, Andrei, and Robert W. Vishny. 1992. "Pervasive Shortages under Socialism." RAND Journal of Economics, 23(2): 237-46.

Shleifer, Andrei, and Robert W. Vishny. 1994. "The Politics of Market Socialism." Journal of Economic Perspectives, 8(2): 165-76.

Simonov, Nikolai S. 2000. "New Postwar Branches (2): The Nuclear Industry," in The Soviet DefenceIndustry Complex from Stalin to Khrushchev. John Barber and Mark Harrison eds. Basingstoke: Macmillan, 150-72.

Sokolov, Andrei K. 2003. "Forced Labor in Soviet Industry: The End of the 1930s to the Mid-1950s: An Overview," in The Economics of Forced Labor: The Soviet Gulag. Paul R. Gregory and Valery Lazarev, eds. Stanford: Hoover Institution Press, 23-42.

Sokolov, Andrei K. 2005. "Before Stalinism: The Defense Industry of Soviet Russia in the 1920s." Comparative Economic Studies, 47(2): 437-55.

Spulber, Nicolas. 1964. Soviet Strategy for Economic Growth. Bloomington, IN: Indiana University Press.

Stalin, I. V. 1937. Voprosy Leninizma. Moscow: Gospolitizdat.

Strauss, Erich. 1969. Soviet Agriculture in Perspective: A Study of its Successes and Failures. London: Allen and Unwin.

Sutton, Antony C. 1968. Western Technology and Soviet Economic Development, 1: 1917-1930. Stanford: Hoover Institution Press.

Sutton, Antony C. 1971. Western Technology and Soviet Economic Development, 2: 1930-1945. Stanford: Hoover Institution Press.

Sutton, Antony C. 1973. Western Technology and Soviet Economic Development, 3: 1945-1960. Stanford: Hoover Institution Press.

Swianiewicz, S. 1965. Forced Labour and Economic Development: An Enquiry into the Experience of Soviet Industrialization. London: Oxford University Press.

Tauger, Mark B. 1991. “The 1932 Harvest and the Soviet Famine of 1932-1933.” Slavic Review, 50(1): 70-89.

Tikhonov, Aleksei. 2003. "The End of the Gulag," in The Economics of Forced Labor: The Soviet Gulag. Paul R. Gregory and Valery Lazarev, eds. Stanford: Hoover Institution Press, 67-74.

United States Department of Commerce. 1960. Statistical Abstract of the United States. Washington, D.C.: U.S. Government Printing Office. 
Vatlin, A. I. 2004. Terror raionnogo masshtaba. "Massovye operatsii" NKVD v Kuntsevskom raione Moskovskoi oblasti. 1937-1938 gg. Moscow: ROSSPEN.

Weitzman, Martin L. 1980. "The 'Ratchet Principle' and Performance Incentives." Bell Journal of Economics, 11(1):302-08.

Wheatcroft, Stephen G. 2004. "From Team Stalin to Degenerate Tyranny," in The Nature of Stalin's Dictatorship: The Politburo, 1924-1953. E. A. Rees, ed. Basingstoke: Palgrave, 79-107.

Wheatcroft, Stephen G., and R. W. Davies, eds. 1985. Materials for a Balance of the Soviet National Economy, 1928-1930. Cambridge: Cambridge University Press.

Wheatcroft, Stephen G., and R. W. Davies. 2002. "The Soviet Famine of $1932-3$ and the Crisis in Agriculture," in Challenging Traditional Views of
Russian History. S. G. Wheatcroft, ed. Basingstoke: Palgrave, 112-46.

Wiles, Peter J. D. 1982. "The Soviet Investment Deflator Again." Soviet Studies, 34(4): 616-17.

Wintrobe, Ronald. 1998. The Political Economy of Dictatorship. Cambridge: Cambridge University Press.

Zaleski, Eugène. 1971. Planning for Economic Growth in the Soviet Union, 1918-1932. Chapel Hill: University of North Carolina Press.

Zaleski, Eugène. 1980. Stalinist Planning for Economic Growth, 1933-1952. Chapel Hill: University of North Carolina Press.

Zolotarev, V. A., ed. Forthcoming. Istoriia sozdaniia $i$ razvitiia oboronno-promyshlennogo kompleksa Rossii i SSSR. 1901-1963 gg. Dokumenty i materialy, 2: Sovetskoe voenno-promyshlennoe proizvodstvo (1918-1926). Moscow: Novyi Khronograt. 